This item was submitted to Loughborough's Research Repository by the author.

Items in Figshare are protected by copyright, with all rights reserved, unless otherwise indicated.

\title{
Carrot or stick: CSR disclosures by Southeast Asian companies
}

PLEASE CITE THE PUBLISHED VERSION

https://doi.org/10.1108/SAMPJ-06-2016-0037

PUBLISHER

(c) Emerald

VERSION

AM (Accepted Manuscript)

PUBLISHER STATEMENT

This work is made available according to the conditions of the Creative Commons Attribution-NonCommercialNoDerivatives 4.0 International (CC BY-NC-ND 4.0) licence. Full details of this licence are available at: https://creativecommons.org/licenses/by-nc-nd/4.0/

\section{LICENCE}

CC BY-NC-ND 4.0

\section{REPOSITORY RECORD}

Arena, Claudia, Ronald Liong, and Petros Vourvachis. 2018. "Carrot or Stick: CSR Disclosures by Southeast Asian Companies". Loughborough University. https://hdl.handle.net/2134/33051. 


\section{Carrot or stick: CSR disclosures by Southeast Asian companies}

\begin{tabular}{|r|l|}
\hline Journal: & Sustainability Accounting, Management and Policy Journal \\
\hline Manuscript ID & SAMPJ-06-2016-0037.R3 \\
\hline Manuscript Type: & Research Paper \\
\hline Keywords: & $\begin{array}{l}\text { Association of South East Asian Nations, CSR disclosure, Legitimacy theory, } \\
\text { Cross-country research }\end{array}$ \\
\hline \multicolumn{2}{|r}{} \\
\hline
\end{tabular}

SCHOLARONE $^{\text {tw }}$

Manuscripts 


\title{
Carrot or stick: CSR disclosures by Southeast Asian companies
}

\begin{abstract}
Purpose - Motivated by legitimacy theory, this paper comprehensively examines CSR disclosure in Southeast Asian (ASEAN) countries with the aim of disentangling whether such disclosures are the result of a proactive stance or a reaction to regulations.

Design/methodology/approach - After a content analysis of CSR stand-alone reports that relies on the Global Reporting Initiative (GRI) as the basis for comparison, a multivariate analysis is carried out while controlling for firm-specific incentives and industry, country and year fixed effects.

Findings - The paper finds that CSR disclosure increased across the entire ASEAN. Although this increase cannot be directly ascribed to the introduction of regulations in Indonesia and Malaysia, the latter may have impacted choices of disclosure media. In countries where reporting requirements have become mandated, mandatory reporters show low levels, and voluntary reporters high levels, of CSR disclosure. The paper also finds that the attainment of CSR awards is related to disclosure. Additional analyses reveal a substitution effect between voluntary and mandatory incentives in countries with high levels of law enforcement.

Originality/value - The paper analyzes not only the level and breadth of CSR disclosure, but also the motivation for its use across the still under-investigated ASEAN area, thus allowing an examination of the influence of institutional incentives above and beyond the firm-specific factors that drive CSR activities.

Practical implications - The evidence suggests that the introduction of regulations can be effective in improving the level and breadth of CSR reporting only in the presence of institutions that ensure the enforcement of the disclosure regulations.

Keywords: Association of Southeast Asian Nations (ASEAN), CSR disclosure, Legitimacy theory, Cross-country research.
\end{abstract}

Paper type: Research paper 


\section{Carrot or stick: CSR disclosures by Southeast Asian companies}

\section{Introduction}

Corporate issuance of stand-alone corporate social responsibility (CSR) reports, often referred to as sustainability reports, has grown dramatically over the past decade (Cho et al., 2012). Although it has been noted that CSR is largely a Western phenomenon (Chapple and Moon, 2005), and hence Asian firms often lag behind their Western counterparts in many aspects of CSR (Baughn et al., 2007), CSR reporting has also increased in Asia, both in terms of the number of companies publishing CSR reports (KPMG, 2016) and the number of academic studies in this field (Fifka, 2012). A recent survey by KPMG indeed reports that over recent years, stand-alone reporting practices have increased by more than $50 \%$ in this region (KPMG, 2016). CSR practices seem to have also been evolved (ACCA, 2010; KPMG, 2016), although related improvements are not on a par with developments in reporting (Ratanajongkol et al., 2006; Gunawan, 2007, 2010; Djajadikerta and Trireksani, 2012).

Despite the range of initiatives to mandate and/or encourage CSR and its reporting (ACCA, 2010; IRI, 2012), very few studies have provided cross-country evidence of the motivations for CSR reporting in Asia to examine whether they differ from the motivations in Western settings. Furthermore, prior studies in this setting typically consider annual reports (e.g., Kuasirikun and Sherer, 2004; Gunawan, 2007, 2010; Kuasirikun, 2011), but no studies to date have explored standalone reporting practices and motivations across Asian countries, which limits the scope of the inferences that can be drawn (Vourvachis and Woodward, 2015). This study fills this gap by comprehensively examining CSR stand-alone reporting practices by companies operating within the Association of Southeast Asian Nations (ASEAN).

Motivated by legitimacy theory and particularly Suchman's (1995) conceptualization, this paper explores whether CSR disclosure by companies within the ASEAN constitutes a reaction to 
increased regulatory pressures (motivated by 'stick' incentives), in accordance with the theory's institutional legitimacy variant, or is a result of a proactive, self-interested stance, in accordance with the strategic legitimacy variant (motivated by some form of 'carrot'-type incentives).

We analyze a sample of 88 unique ASEAN companies corresponding to 236 firm-year observations over the period 2002-2012, and we proxy 'stick' incentives using the regulatory requirements that mandate CSR reporting in Indonesia and Malaysia, while we capture 'carrot' incentives by relying on the CSR awards received by ASEAN companies. We find little evidence that CSR disclosure increased across the entire ASEAN area after the introduction of regulations, casting doubt on the 'stick' type of motivation for disclosure. We also note that in the mandatory settings (Indonesia and Malaysia), new mandatory reporters provide a low level of disclosure, while companies that were disclosing before the regulations were promulgated (voluntary reporters) tend to disclose a high level of CSR information. Detailed descriptive analyses of the companies examined reveal substitution effects between annual and stand-alone reports, with information about certain categories such as product responsibility and human rights actually decreasing overall as organizations redrafted their reporting agendas following the regulations.

In line with prior studies (Boesso and Kumar, 2007; Anas et al., 2015), we find that CSR awards are associated with higher disclosure, supporting the hypothesis that 'carrot' incentives also play a role. We show, however, that the effect of 'carrot' and 'stick' motivations is not uniform across different regulatory regimes. We find that in countries with high-quality legal systems (i.e., Brunei, Cambodia, Laos, Malaysia, Singapore, Vietnam), 'stick' incentives exert a positive effect on CSR disclosure, while 'carrot' incentives matter most in low-quality regulatory settings (i.e., Indonesia, the Philippines, Thailand). The findings support the argument that 'carrot' incentives might substitute for 'stick' incentives, particularly in regulatory regimes that do not ensure the effective application of rules and regulations. 
Overall, our study contributes to the literature by adopting a cross-country approach, considering the entire ASEAN region rather than a single country (as in, e.g., Haji, 2013 and Saleh, 2009). We are therefore able to differentiate among the institutional systems in each country and provide additional evidence on the determinants of CSR reporting. Furthermore, our study can be differentiated from prior research that focuses on a single CSR disclosure category (e.g., Cahaya et al., 2012; Connely and Limpaphayom, 2004) and that predominantly analyzes annual reports (e.g., Kuasirikun and Shere, 2004; Le, 2011; Ratanajongkol et al., 2006) and/or website disclosures (e.g., Chapple and Moon, 2005; Williams and Pie, 1999) by capturing not only the overall level but also the breadth of CSR disclosure and by focusing on under-investigated stand-alone CSR reporting practices (Boiral, 2013; Mahoney et al., 2013; Michelon et al.. 2015), particularly within the ASEAN region.

The remainder of the study is organized as follows. The next section presents the detailed backgrounds of Asian countries and the prior findings from research in the area. Then, the theoretical framework and hypotheses are developed. The methods employed in the study are subsequently presented, followed by the results and the concluding section, in which the key findings are discussed.

\section{CSR reporting in the ASEAN region}

Asian countries differ substantially in social, economic, political and legal terms from their Western counterparts (Baughn et al., 2007). Ang and Leong (2000) suggest that the values associated with Asian businesses, such as the cultivation of special relationships and the sharp distinction between 'insiders' versus 'outsiders', contribute to the lesser extent of CSR business practices in the region. The inherent modesty in Asian cultures works against providing disclosure of CSR activities, and therefore, some activities may not be as readily discerned by outside observers (Welford, 2005). Furthermore, Western cultures tend to also codify their social relations with rules, while Asian firms rely more on more informal cultural mechanisms, such as their philosophy and guiding 
principles, which may have significant implications for CSR activities and related regulations across countries (Baughn et al., 2007). In support of this claim, Ramasamy and Hung (2004) observe a low level of CSR awareness in Malaysia, where it is generally lower than that found in Singapore. Chapple and Moon (2005) also note that in both Thailand and Malaysia, there is a much greater emphasis on community involvement compared to employee relations. Singapore's small size and dense population, however, has amplified concerns about environmental policies (Kimber and Lipton, 2005). Baughn et al. (2007) find that Malaysia and Singapore have comparable levels of CSR disclosure despite the significant differences in their levels of economic development. To date, however, there has been very limited research on the differences (as well as on what drives these differences) in CSR reporting across countries in the Asian context (Chapple and Moon, 2007).

This appears to be particularly the case within the ASEAN area (ACCA, 2010). Formed in 1967, ASEAN includes Brunei, Cambodia, Indonesia, Laos, Malaysia, Myanmar, the Philippines, Singapore, Thailand and Vietnam. Collectively, ASEAN represents a market of over 600 million people, with a combined GDP of approximately US $\$ 1.8$ trillion. If it were a country, ASEAN would be the ninth largest economy in the world and the third Asian dragon in terms of its development as an emerging economy. Interestingly, it is a region where the countries differ in terms of the legal environment, level of economic development, population size, religious affiliation, and languages. This makes ASEAN an ideal setting to examine not only the level and the trends of CSR reporting over time but also the motivating factors that drive CSR disclosures across countries.

It has indeed been noted that within the region, a range of initiatives have been adopted to mandate and/or encourage CSR and its reporting (ACCA, 2010; IRI, 2012). Voluntary incentives may include awards (concerning reporting or general corporate responsibility), training (provided by CSR ASIA and other organizations), participation in an index (such as the Asian Sustainability 
Rating, the Kehati-SRI index or CSR rankings such as the Channel News Asia sustainability ranking), or voluntary codes offering certification (e.g., GRI, the UN Global Compact, OECD guidelines, ISO26000, or the PRI reporting framework), among other incentives.

In contrast, mandatory requirements typically refer to formal or informal laws and principles (ACCA, 2010; IRI, 2012). Two ASEAN countries have introduced CSR reporting regulations: Indonesia and Malaysia. Primarily motivated by the need to address environmental degradation ${ }^{1}$, the Indonesian Capital Market Supervisory Agency introduced a new rule, Bapepam-LK rule X.K.6, on 7 December 2006, which made it compulsory for public companies to provide a "description of the activities and expenditures related to corporate social responsibility towards society and the environment" (ACCA, 2010). XK6 was followed one year later by Law No. 40/2007 Concerning Limited Liability Companies Law (or Law 40/2007), which mandated that companies include environmental and social programs in which they participate in their reports (ACCA, 2010).

Similarly, the Malaysian government announced CSR disclosure requirements for public companies in the 2006 and 2007 budgets. Debates regarding the introduction of the CSR law occurred for a number of years (Amran and Haniffa, 2011). In 2004, the then Minister of Finance suggested that the government "strongly supports the adoption of voluntary CSR reporting and standards" and stated that "the government does not favour regulations interfering with the private sector's CSR initiatives" (ACCA, 2010, p. 31). However, in 2006, the government decided to introduce regulations, albeit broadly stated, in order to "inculcate the culture of corporate social responsibility" (ibid.). The 2006 budget involved the disclosure of CSR activities, while the 2007 budget compelled the disclosure of workforce statistics by race and gender, in addition to “programmes conducted to develop Bumiputra vendors" (ACCA, 2010).

\footnotetext{
${ }^{1}$ As Judge M. Jahfud M.D. said in an attempt to defend the law, "Environmental damage in Indonesia has reached a critical level... It's time for the state, along with society and businesses, to be responsible for the negative impacts of the damage" (ACCA, 2010, p. 30).
} 
In both countries, therefore, CSR regulations became effective in 2007 as part of the countries' listing requirements, although they were evidently very broadly stated, lacked formal guidance visa-vis both the type and extent of disclosure, and provided no audit requirement (ibid.).

\section{Theoretical framework}

The theoretical framework of the study is legitimacy theory (Lindblom, 1993; Suchman, 1995). Legitimacy theory has been employed widely in recent decades by researchers seeking to examine CSR reporting practices, and it appears to be the most cited theory in the CSR field (Vourvachis and Woodward, 2015). Legitimacy theory is centered on the notion of a social contract, whereby a "business agrees to perform various socially desired actions in return for approval of its objectives, other rewards and ultimate survival" (Guthrie and Parker, 1989, p. 344). Although the concept of the social contract has been criticized by Spence et al. (2010), as a society could include several publics that differ in terms of "values, interests, powers and perceptions" (p. 81), the theory may be particularly applicable in our context, where the impact of regulation is explored in multiple settings (Criado et al., 2008). As Deegan (2000) notes, "[i]t can be argued that the requirements imposed by the law reflect the explicit terms of the social contract, while uncodified community expectations (and these will be perceived differently by different people) constitute the implicit terms of the social contract" (fn 7, p. 254).

Suchman (1995) suggests that there are two major views of legitimacy theory - institutional legitimacy and strategic (or organizational) legitimacy (his views are echoed by Gray et al., 1995; Chen and Roberts, 2010). From an institutional perspective, attempts to legitimate are controlled by institutional pressures that create tendencies toward isomorphism within an organizational field (DiMaggio and Powell, 1983). Therefore, management practices with respect to CSR decisions are constructed by external institutions. As Gray et al. note, "this process of institutionalisation is presumed to occur through a combination of coercion (e.g., regulations, laws or major market changes), normative mechanisms (shared and converging values through, e.g., education or 
professionalization) and mimetic mechanisms (typically imitation of behaviours that appear to be successful)" (2010, p. 26, emphasis in original). From this perspective, legitimacy is gained by the organization becoming isomorphic with its environment (Meyer and Rowan, 1977).

From a strategic perspective, on the other hand, legitimacy can be influenced or manipulated by organizations to gain societal support. Authors ascribing to this view attempt to identify different strategies that organizations seeking legitimacy may adopt (see, e.g., Dowling and Pfeffer, 1975; Lindblom, 1993). CSR activities are therefore seen as a means of image building to maintain or improve the organization's economic position by "attracting 'patient' shareholders and enhancing the firm's reputation and brand value... [to] reduce stock price volatility... make... a brand name and affect share prices... [and] enhance [its] reputation, which leads to greater financial value" (Clikeman, 2004, p.25).

These perspectives are generally viewed in the literature as complementary and by no means mutually exclusive (Larrinaga-Gonzalez, 2007; Chen and Roberts, 2010; Gray et al., 2010). It is also worth noting that under legitimacy theory, a change in CSR disclosure does not necessarily reflect a company's commitment to transparency. Disclosure is rather used to manipulate stakeholders' perceptions about the company, to indicate compliance and/or to allow the company to pursue other objectives. In this regard, several studies highlight that poor performers tend to provide more extensive CSR disclosure, however of a primarily positive nature, which is ultimately less informative about the firm's underlying performance (Guthrie and Parker, 1989; Cho and Patten, 2007; Vourvachis et al., 2016). These arguments are also supported by several prior studies in the ASEAN literature (e.g., Ratanajongkol et al., 2006; Gunawan, 2007, 2010; Djajadikerta and Trireksani, 2012) though would be incompatible with the aforementioned modesty inherent in Asian culture (Welford, 2005). Notwithstanding the above arguments, often termed 'decoupling' (e.g., Amran and Haniffa, 2011; Graafland and Smid, 2016), our study primarily focuses on the institutional/coercive and strategic influences on CSR disclosure as opposed to deviations from the 
underlying CSR performance (although inferences to the latter are also tentatively made when our findings allow us to do so).

\section{Hypotheses development}

\subsection{Stick incentives and CSR reporting in the ASEAN region}

According to legitimacy theory, therefore, organizations engage in CSR reporting for two main reasons: first, in response to institutional pressures (i.e., motivated by 'sticks') to ensure legitimacy for their operations; or second, they could use disclosures proactively to manipulate perceptions and seize associated economic benefits (i.e., motivated by some sort of 'carrot'). While the institutional legitimacy perspective encompasses a variety of coercive incentives to produce CSR information, as per Gray et al.'s aforementioned arguments, perhaps the most 'typical' example of a 'stick' motivation would be the introduction of regulations. In this context, organizational compliance with any CSR reporting regulation would help ease related institutional pressures and assist companies in enhancing their legitimacy (Meyer and Rowan, 1977).

As appendix A1 indicates, studies examining the impact of CSR regulations on disclosure have looked at a variety of regulatory initiatives and have primarily focused on more developed countries. These regulatory initiatives have clearly had varying degrees of success. It seems, however, that in the majority of cases where a formal law requiring broad CSR disclosures (as in the present study) was introduced (with the exception of Luque-Vilchesz and Larrinaga, 2016), it had a positive impact on levels of disclosure, albeit with variations in the level of compliance and the quality of disclosure. Conversely, when initiatives requiring the disclosure of specific information were introduced, they were typically associated with a low level of compliance (but see Patten, 2000, Llena et al, 2002, and Freedman and Stagliano, 2008, for exceptions).

Failures to improve CSR reporting following the introduction of regulations have been attributed to a lack of 'normativity', i.e., the degree to which rules and practices become accepted and 
standardized. Bebbington et al. (2012) note that normativity can arise not only from the enforcement of formal laws but also from less formal systems (e.g., shared beliefs about the norm's legitimacy or internal morality). Chauvey et al. (2015) find high levels of disclosure following the introduction of a formal law in France. However, these disclosures are of generally low informational quality, suggesting that the regulator's objectives have not been met. Nevertheless, the authors show that normativity can be achieved over time as long as it reaches a diffusion stage and CSR disclosure becomes a taken-for-granted practice.

In the developing country context, Weber (2014) reports that the introduction of a formal law requiring CSR disclosure in China led to an increase in the level of disclosure, with nevertheless varying reporting quality. Similarly, Ioannou and Serafeim's (2014) and (2017) studies find increased levels of disclosure following the introduction of regulations in both China and South Africa. With respect to Malaysia, although the authors initially found no effect on CSR disclosure, they later reported significant post-regulation increases. Nevertheless, specific attributes of the setting, such as a preference for informal law (Baughn et al., 2007) and the inherent modesty in Asian cultures (Welford, 2005), may also affect the normativity of introduced regulations. Hence, we formulate our first hypothesis as follows:

H1: CSR disclosure is higher in ASEAN firms that are mandated to report on CSR compared to non- mandated ASEAN firms.

\subsection{Carrot incentives and CSR reporting in the ASEAN region}

On the other hand, organizations may voluntarily seek to participate in a number of 'carrot' initiatives, such as awards, training, voluntary codes and other incentives, in order to manipulate constituents' perceptions, which is consistent with the strategic legitimacy perspective. Awards are nevertheless seen as the most 'representative' carrot incentive, and they indeed appear to have been more frequently empirically explored in the literature (see e.g. Boesso and Kumar, 2007; Anas et 
al., 2015; KPMG, 2016). Although there are clear variations in types of potential awards received (in terms of e.g. relationship with underlying performance, legitimacy of the awarding body and publicity), organizations could attempt to increase their CSR disclosure in order to obtain related awards and consequently additional support for their operations as well as to close any related legitimacy gaps (Ryan et al., 2002).

In Australian settings, Ryan et al. (2002) and Deegan note the positive publicity and external validation benefits associated with receiving awards as well as their potential to reduce political costs, such as, e.g., minimizing the likelihood that unions will be able to justify further wage claims against a firm. Furthermore, as Deegan and Carroll (1993) suggest, award winners "may reduce the likelihood of confrontation, reduce the arguments that the firm is not acting responsibly, and decrease the likelihood of further specific legislation" (p. 222). In this vein, Boesso and Kumar (2007) find a significantly positive association between the extent of voluntary disclosure practices among their sampled Italian and US companies and the assignment of awards.

In the ASEAN context, the ACCA (2010) report suggests that CSR disclosure in Indonesia and Malaysia has been significantly affected by voluntary initiatives such as codes and awards. A number of organizations have been established to support and promote CSR reporting in these two countries, such as the Indonesian National Center for Sustainability Reporting and the Malaysian ACCA Sustainability Reporting Awards. In particular, a number of authorities (including governments) have introduced CSR awards, which subsequently became important elements in the disclosure practices of listed companies (Anas et al., 2015). KPMG (2016), in exploring 'carrots' and 'sticks' instruments throughout the world, also notes the increase in voluntary initiatives in the ASEAN region and highlights the role of awards. The report finds that the proportion of voluntary to mandatory instruments in the area is among the highest in the world.

Nevertheless, as appendix A2 indicates, several studies have analyzed CSR disclosure in the ASEAN region, but only a few of those identified explore the influence of voluntary initiatives on 
CSR reporting. These studies focus on Malaysia, and their findings suggest that there is a significantly positive relationship between awards and CSR disclosure. Haniffa and Cooke (2005) particularly highlight awards as a key contributor to the sustained high levels of disclosure over time by voluntary reporters. Amran and Haniffa (2011) additionally note that pursuing awards can help companies increase their relevant stakeholders' trust and enhance their business networking, while Anas et al. (2015) also strongly suggest that awards significantly and positively influence the extent and quality of CSR disclosure. We therefore expect that the above findings, and particularly those from Malaysia, will hold across the entire ASEAN region, and we therefore formulate our second hypothesis as follows:

H2: CSR disclosure is higher in ASEAN firms that receive CSR awards compared to ASEAN firms that do not obtain CSR awards.

\section{Research Methodology}

\subsection{Sample description}

The study focused on ASEAN companies over the period 2002-2012. An attempt was made to identify all publicly available CSR reports produced by ASEAN companies. Appendix A3 reports the sample distribution. Panel A shows that 236 reports from nine ASEAN countries were identified. Only reports in English or in a combination of English with another language were considered. Although attempts were made to include each ASEAN country, no CSR reports from companies based in Myanmar could be located ${ }^{2}$.

There has been a significant increase in organizations' engagement with CSR reporting over the years, both in terms of the number of reports published as well as in terms of GRI compliance. Prior

\footnotetext{
${ }^{2}$ Appendix A3 shows what appears to be a low number of reports in 2012. This is due to the fact that the data collection was carried out before June 2012; thus, it was not possible to retrieve all the reports for that year. Table 1 also shows that for some countries (i.e., Vietnam, Cambodia, Laos and Brunei), we have only one company. These are small private firms in the financial and services sectors that provide low levels of disclosure. As a robustness test, we re-ran our analysis excluding companies from these countries, and our results remain unchanged.
} 
to 1990, CSR reporting was almost non-existent in Southeast Asia (ACCA, 2010). CSR disclosures lacked a formal structure and were often made in passing via the Chairman's Statement in the annual report, or worse, they were provided in newsletters and company magazines that were only available internally (Teoh and Thong, 1984). Later, CSR reporting progressed to become more formalized and substantive. Companies in Southeast Asia started releasing environmental and health and safety reports in 1990, social reports in the mid-1990s, and eventually the first comprehensive CSR report in 1999, coinciding with the first GRI index (ACCA, 2010).

Consistent with this picture, we find that from 2002 to 2006, very few companies issued CSR reports (22 obs.). Among them, 63.63\% are from Indonesia (8 obs.) and Malaysia (6 obs.), and these reports exhibit on average a high level of CSR disclosure $(33.23 \%$ ), while the remaining companies are from Cambodia (4 obs.), Thailand (3 obs.) and Singapore (1 obs.) and report on only $10 \%$ of the GRI indicators. Examining the characteristics of these companies, we find that most of them are large listed companies operating in the manufacturing (37.37\%), extractive $(27.27 \%)$ and construction industries (9.09\%). However, from 2007 onward, we observe an increasing trend of the sampled firms issuing CSR reports. The trend is stronger for Indonesian and Malaysian companies in 2007 and 2008. Interestingly, during this period, CSR reporting became mandatory in these countries.

After the issuance of these regulations, we observe that the number of Indonesian and Malaysian companies disclosing CSR information significantly increased. However, a similar trend was noted in other ASEAN countries, which became more evident after 2009 and could be attributed to mimetic isomorphism. Indeed, in the period 2009-2012, the rate of adoption of CSR reports for companies operating in other ASEAN countries was higher than that observed for Indonesian and Malaysian companies.

\subsection{Disclosure variables}


To gather our disclosure data, we rely on a manual content analysis of the CSR reports using the GRI 3.1 index as the coding base. Content analysis is "the research method that is most commonly used to assess organisations' social and environmental disclosures" (Milne and Adler 1999, p. 237). It can be used to draw logical inferences by analyzing large quantities of reports in terms of their disclosures and omissions (Kaisirikun and Sherer, 2004). The GRI 3.1 index is used as our coding framework because it is recognized as a de facto international reporting standard (Young and Dhanda, 2013). Given the multi-stakeholder development process of the GRI index and the diverse reporting requirements, it can also be viewed as a list of information demanded by stakeholders. GRI has been praised for its global, consistent yet holistic approach based on the triple bottom line: social, environmental and economic aspects (Bouten et al., 2011). Indeed, its consistent, uniform approach to CSR reporting makes it in practice the only universally accepted standard for such a purpose (Lodhia, 2012).

For the purposes of this study, the CSR reports have been analyzed against the Profile and Performance Indicator Disclosures listed in the GRI 3.1 index. Based on this analysis, a score on a scale from 0 to 1 is awarded for each disclosure item (e.g., EN1, SO7). One point is awarded for full disclosures, if a reference is made to another document or webpage where a full disclosure is made, or if a substantive explanation for omission is provided. Substantive explanations refer to explanations provided by the company in the report. These may include immateriality, irrelevance or "not applicable" with valid reason (e.g., no substantial fines). Partial disclosures and the inclusion of plans to begin disclosing in a future report are awarded 0.5 points. No points are awarded for omissions without explanation.

We then add up the single item scores within each category (e.g., SOCD: social performance disclosures, ENVD: environmental performance disclosures, and OTHERD: strategy, operations and report profile, corporate governance and economic indicators) and normalize the value to 1 by dividing the category score by the maximum score possible (equal to the number of indicators or 
items required in each GRI category). These measures examine the breadth of CSR disclosure, that is, the provision of CSR information across different areas of social and environmental disclosure (Chauvey et al., 2015). Following the well-established practice in CSR disclosure studies (Cho and Patten 2007; Cho et al. 2006; Patten and Trompeter, 2003), we further employ a social and environmental disclosure score (SED) to measure the overall level of CSR disclosure for each firm. Details of our coding scheme, along with illustrations of how these codes were applied, are available from the authors on request. It is worth noting that our CSR disclosure measures capture the level and the breadth of CSR disclosure but do not provide evidence of its informational ‘quality'.

An issue in meaning-oriented content analyses that rely on a proprietary, hand-collected database is the subjectivity and reliability of the coding (Milne and Adler, 1999). To avoid intra- and intercoder subjectivity and produce reliable disclosure measures, we defined a coding procedure and ran a pilot test during which two authors independently applied the coding procedure to a sub-sample that covers companies of various sizes from various countries and industries. We compared the results of the pilot test and identified and resolved misalignments by revising the coding procedure. Then, we conducted another round of pilot tests that resulted in a reliable coding procedure. The kappa-statistic measure of agreement among coders is 0.0082 (p-value $<0.001$ ), suggesting an appropriate level agreement (85\%) according to Landis and Koch's scale (1977).

\subsection{Independent variables and controls}

To capture the effect of the issuance of regulations on the overall sample, we take into account that CSR reporting in the ASEAN region became mandatory for both Malaysia and Indonesia in 2007; hence, we introduce a dummy variable that equals 1 for the period ending on or after 2007 (Post). Then, following prior studies examining the disclosure effects of new regulations (Daske et al., 2008; Horton et al., 2013), we divide the companies in the sample from countries where CSR reporting became mandated into two groups: mandatory and voluntary reporters. First, we define a 
dummy variable (Mandatory) that takes the value of 1 for firms that did not disclose CSR until it became mandatory. Then, we introduce a separate indicator variable (Voluntary) that takes the value of 1 for firms that reported CSR information in a CSR report or as part of their annual report before it was mandated. We also define an interaction term (Voluntary_Post) for all fiscal years ending on or after the mandatory introduction of regulations for the voluntary reporters.

Our variable of interest for testing $\mathrm{H} 2$ is Awards, which is a continuous variable that equals the total number of CSR awards received by a company. To this aim, we identify CSR awards (either monetary or non-monetary) that receive a higher amount of media coverage, which might lead companies to increase their CSR disclosure in response to underlying pressures (Boesso and Kumar, 2007) ${ }^{3}$.

Our multivariate analysis aimed at testing $H 1$ and $H 2$ relies on the following equation ${ }^{4}$ :

$$
\begin{aligned}
\text { Disclosure }=b_{0}+ & b_{1} \text { Post }+b_{2} \text { Mandatory }+b_{3} \text { Voluntary }+b_{4} \text { Voluntary_Post } \\
& +b_{5} \text { Awards }+\sum_{i} \text { biContr }
\end{aligned}
$$

where Disclosure is alternatively equal to $S E D, E N V D$, SOCD or OTHERD, as previously defined. The main coefficient of interest for testing $H 1$ is $b_{2}$, which captures the level of CSR reporting

\footnotetext{
${ }^{3}$ A prominent CSR reporting award in the region is the Asian Sustainability Rating. Launched in 2009, it offers an online tool for companies and their stakeholders with regard to sustainability disclosure. The ACCA Malaysia Sustainability Reporting Awards, originally launched in 2002 as ACCA Malaysia Environmental Reporting Awards, is another prominent award promoting transparency (ACCA, 2010). More recently, the Asia Pacific Awards (2011) and the CSR Malaysia awards (2016) have been developed. The latter aims to honour corporations in Malaysia that promote the socio-economic transformation of the country - it is supported by the Ministry of Women, Family and Community Development. In Indonesia, the National Center for Sustainability Reporting (founded in 2005) is cooperating with GRI in promoting the annual Indonesian Sustainability Report Award. The Indonesian Biodiversity Foundation KEHATI, in partnership with the Indonesian Stock Exchange, launched a sustainability index in 2009, promoting good CSR and governance practice (ACCA, 2010). All awards receive considerable media coverage, as our un-tabulated analysis of companies' media exposure indicates.

${ }^{4}$ We perform GLM regressions (logit link function), since our dependent variable is defined as a proportion. All models include country, industry and year fixed effects. We compute robust standard errors to control for heteroskedasticity.
} 
around the issuance of regulations in Indonesia and Malaysia for firms that were essentially forced to disclose their CSR activities. The coefficient $b_{3}$ captures the level of CSR reporting for voluntary adopters, i.e., firms that had started disclosing before the introduction of mandatory reporting, while the coefficient $b_{4}$ captures any incremental (period-specific) effects for voluntary adopters once regulations were adopted. To empirically support $H 2$, we would expect the coefficient for Awards $\left(b_{5}\right)$ to also be positive and significant.

Based on legitimacy theory, we further control for the following firm-specific characteristics, which could reflect additional incentives to disclose CSR activities. First, in recognition that media exposure may increase the extent of CSR disclosure (Aerts and Cormier, 2009; Aerts et al., 2008; Deegan et al., 2000), we control for media exposure (Media) by counting the total number of media articles retrieved from Lexis/Nexis. Then, following the stream of literature suggesting that corporate governance factors may affect the extent of CSR disclosure (Mallin and Michelon, 2011, Arena et al., 2015), we introduce two indicator variables to capture whether a company has provided executives with incentive compensation linked to CSR outcomes (CSR_Comp) and whether the board of directors has introduced an ad hoc CSR Committee (CSR_Comm). We also consider the effect of company reputation, which is measured by whether the company participates in a CSR index (CSR_Index) and whether the company complies with voluntary codes or regulations that call for more responsible business actions (e.g., UN Global Compact, OECD guidelines, ISO26000, PRI reporting framework, PROPER Code, Silver Book) (Sust_Code). Following the well-established literature that suggests that CSR reporting varies across sensitive and non-sensitive industries (Deegan and Gordon, 1996; Brammer and Pavelin, 2008; Liu and Anbumozhi, 2009), we include membership in environmentally sensitive industries (i.e., oil exploration, paper, chemical and allied products, petroleum refining, metals) with a categorical variable that equals 1 if the company belongs to such industries, as defined by Cho and Patten (2007), and 0 otherwise (ESI). We also control for firm size (Size) as a measure of firm visibility 
(Patten, 1992) as well as for leverage (Lev) and profitability $(R O E)$, in order to take into account the effect of financial factors that do not reflect legitimacy (Chauvey et al., 2015). Finally, we take into account the public/private status of the firm (Status). Table A4 provides details on the variable definitions and measurements.

\section{Results \\ 6.1 Descriptive analysis and univariate tests}

This section presents the results of the first stage of our analysis on CSR disclosure in the ASEAN region. First, some summary information about the characteristics of the sample companies is provided in Table 1. On average, firms report on $37.9 \%$ of the GRI social and environmental indicators. With regard to the breadth of CSR reporting, it seems that the sampled companies report more environmental than social information. However, the companies seem to provide high levels of other types of information, such as strategy and governance information. Furthermore, we observe that ASEAN companies received on average 17 CSR awards, with a minimum of 0 and a maximum 120. In our sample, the companies are highly subject to media pressure, as determined by the mean value of press articles on the companies. With regard to the other characteristics of the sample companies, only $33 \%$ of firms' boards have a formal CSR committee, while $6.3 \%$ of the firms link managerial compensation to CSR outcomes. We can also note that approximately $11 \%$ of the sampled companies participate in a CSR index (typically the Kehati-SRI index, Asian Sustainability Rating and Channel News Asia Sustainability Ranking), and 33.8\% of them operate in environmentally sensitive industries. Conversely, the majority of the sample tends to comply with voluntary sustainability codes. This result is in line with the high diffusion of voluntary CSR initiatives documented in the ASEAN region (ACCA, 2010). Finally, we observe that the average sample company is a large listed firm that is highly leveraged with positive profitability.

Insert Table 1 about here 
Table 2 provides detailed information on the average number and type of CSR awards per country. Specifically, we can observe that on average, Thai companies receive the highest number of CSR awards, followed by companies in Indonesia, Singapore and Malaysia. With regard to the type of CSR awards across all the sample countries, we can observe that reporting awards represent a small proportion of the total awards, whereas there were almost no monetary awards. The majority of the awards are related to general CSR aspects such as awards for company of the year, customer service, individual employees, health and safety and reputation. Finally, Table 2 reveals variations by country in regard to whether awards are earned by companies that participate in a CSR index. A small number of companies participated in a CSR index, and these companies were also typically CSR award winners, as the statistically significant correlation (at the 0.05 level) suggests.

\section{Insert Table 2 about here}

Table 3 provides details on the disclosure scores by country. It is interesting to note that other nonCSR related disclosures related to strategy and analysis (Str), organizational profile $(O P)$ and report parameters $(R P)$ are the most provided in every country. Given the nature of this information, we observe that related disclosure scores usually reach the maximum of 1 only in some countries and for some specific items. On average, we observe that governance, commitments and engagement $\left(G o v \_D\right)$ are the most disclosed information by companies from Indonesia, the Philippines and Singapore, while environmental information $\left(E n v_{-} D\right)$ as well as labor practices and decent work $\left(L a b \_D\right)$ information are mainly provided by Indonesian and Filipino companies. Indonesian and Malaysian companies provide also more human rights $\left(H R \_D\right)$ and product responsibility disclosures (Prod_D). This result confirms that of prior studies (Andrew et al., 1989; Saleh, 2009; Gunawan, 2010) suggesting a greater emphasis on employee rather than environmental disclosure in emerging countries. In this regard, it has been argued that there can be three major reasons leading companies to report less on environmental issues, i.e. (i) low environmental awareness, (ii) lack of perceived benefit, (iii) lack of government pressure (Perry and Sheng, 1999). 
Conversely, social information $\left(S_{-} \_D\right)$ is mainly disclosed by Indonesian and Thai companies. These findings are consistent with those of Ratanajongkol et al. (2006) and Gunawan (2015) that consider the "community" as the key-effected group driving CSR reporting practices in these countries, supporting a legitimacy-based explanation for CSR disclosure.

\section{Insert Table 3 about here}

Table 4 summarizes the mean scores on CSR disclosure for the firms in our sample across the 20022006 (PRE) and 2007-2012 (POST) periods. As shown in Table 4, Panel A, the average number of CSR disclosures of ASEAN firms showed a significant increase in the period after the issuance of the regulations. With regard to the breadth of CSR disclosures across the different areas in the preand post-regulation periods, we observe a significant increase in the amount of environmental information and slightly lower increases for social and other types of disclosures. However, as noted above, the only two countries in the region mandating CSR disclosure were Indonesia and Malaysia. For this reason, we separately computed the mean CSR disclosure scores for the subsample of firms from only these two countries. As shown in Table 4, Panel B, the changes in CSR scores across all four areas of CSR reporting are not statistically significant except for the "other" information. However, this may largely be due to the already high level of CSR information provided by companies from these two countries in the period before CSR disclosure became mandated, potentially in anticipation of the new regulations.

Insert Table 4 about here

To more carefully assess the potential impact of the regulations, in Table 5, we computed the average variation in CSR disclosures from 2006 to 2007. However, we observe no significant differences at conventional levels in the entire ASEAN region (Table 5, Panel A) or among Indonesian and Malaysian companies (Table 5, Panel B).

Insert Table 5 about here 
To obtain a more comprehensive picture of the effect of the regulations in Indonesia and Malaysia, we explicitly take into account that companies from these countries might have also reacted to the issuance of the regulations by adjusting the breadth and level of CSR disclosure provided in their annual reports. Hence, we re-run our analysis of Tables 4 and 5 to capture changes in the level of annual report CSR disclosure for Indonesian and Malaysian firms. Table 6 shows the results of this analysis. Panel A highlights that the average score for CSR disclosure in annual reports increased significantly. In line with what we previously observed for stand-alone reports, there were greater increases in disclosures of environmental information and social information. Focusing on the years across the regulatory changes (Panel B), we find that companies from Indonesia and Malaysia showed significantly increased disclosures of CSR information in their annual report, most of which relates to the environment.

\section{Insert Table 6 about here}

Overall, the assessments of changes in the level of CSR disclosure seem to indicate that ASEAN firms increased their disclosure of this information significantly over the years, but this increase cannot be directly ascribed to the introduction of regulations in 2006 and 2007. To examine the trends in CSR disclosure in ASEAN countries in more detail, we provide additional qualitative evidence on the single disclosure items gathered from the content analysis of the CSR reports. We combine this evidence with discussions of the key changes noted for companies reporting in the pre- and post-regulation periods in Indonesia and Malaysia, as reflected in Table $7^{5}$.

\section{Insert Table 7 about there}

\footnotetext{
5 For the purposes of this analysis, we examined the sub-sample of Indonesian and Malaysian companies producing annual and CSR reports in 2006 and 2007. The five companies that produced annual reports in 2006 were British American Tobacco and Malaysian Airlines from Malaysia and Medco, Telkom and Holcim from Indonesia. All of these companies also produced CSR reports in that year, although our related sub-sample also included ANTAM and KPC (both from Indonesia). Most of the companies operated in the mining, energy and construction and materials sectors. All the companies were large, regularly produced CSR and annual reports throughout the examined period and typically received a higher than average number of awards, including for reporting. Most were also members of an index (except for Holcim and KPC).
} 
Over the period analyzed, improvements were made in all areas of strategy, profile and governance disclosure. This could be a sign of a learning curve as companies gradually learn to appreciate the issues raised by the GRI framework, though it could also be interpreted as a sign of ASEAN companies attempting to demonstrate good corporate governance in the wake of the global financial. As Table 7 reveals, however, the introduction of regulations may have caused some substitution effects from CSR reports to annual reports, while there were also areas such as shareholder feedback and links between executive remuneration and performance where a decreased level of average compliance was noted. Improvements were also observed in all performance indicators over the most recent five years of the analysis, especially with respect to human rights, social issues, and product responsibility. Interestingly, in all three areas, a general decrease in disclosure compliance was noted in the immediate year post-regulation.

With respect to the economic performance indicators, references to direct economic value generated and distributed and to defined benefit plan obligations are more frequently made, which echoes their mandatory nature in the financial reports. Table 7 notes some substitution effects for indicators about infrastructure investments and indirect economic impacts though in general disclosure either remained constant or increased post-regulation for most indicators in this category. With regard to the environmental performance indicators, the most consistently reported are those related to energy, water usage and greenhouse gas emissions. Conversely, a low level of disclosure is observed for packaging materials reclaimed by category, reflecting the poor recycling habits in Southeast Asia and the lack of infrastructure to allow companies to reclaim packaging from their customers. Table 7 reveals an increased emphasis on environmental disclosures in annual reports in 2007; however, it also reveals a decreased emphasis in CSR reports.

The substitution effects between the disclosure media post-regulation are also evident in the labor practices performance indicators. Overall, as the earliest forms of CSR reporting in Southeast Asia related to labor practices, perhaps it is unsurprising to find that this area tended to have the highest 
disclosure levels. Interestingly, employee turnover breakdown, full-time employee benefits and the gender pay gap were not substantially discussed in the 2007 reports, but related discussion was considerably extended by 2011. Disclosures in the product responsibility category however seem to have been negatively affected by the introduction of regulation, as the related disclosure either decreased or remained constant for all indicators.

Among the most poorly disclosed indicators throughout our examined period are those related to human rights. As Table 7 reveals, there was almost no mention of human rights in annual reports, and this type of disclosure decreased in CSR reports before picking up in the later years of the analysis. The minimal early disclosure may indicate that human rights was a taboo topic across the region (in the sense of Kallio, 2007) prior to improvements in later years. Social performance disclosure also generally decreased across the disclosure media in 2007. Perhaps the most intriguing disclosure items relate to corruption, which all decreased in 2007, although evidence of improvement was shown in subsequent years. Interestingly, for items such as fines and negative impacts on communities, we notice a substitution effect from AR to CSR, which suggests an attempt to conceal negative news by providing disclosures in media with potentially less readability and a smaller critical audience.

\subsection{Multivariate analysis}

Our second stage of analysis focuses on the motivations for CSR practices and aims to assess whether the differences in disclosure among our sample ASEAN firms are associated with 'stick' and/or 'carrot' incentives. Table 8 reports the results for model (1) that tests our research hypotheses.

\section{Insert Table 8 about here}

Column (1) shows the results for the overall CSR disclosure score. With respect to $H 1$, the evidence is mixed. We find that the coefficient on Post is positive and significant, suggesting that after the issuance of the regulations, CSR disclosure increased for all ASEAN companies. However, 
focusing on companies in Indonesia or Malaysia, we find that companies that began disclosing after the issuance of regulations (Mandatory) show generally low levels of CSR disclosure. In contrast, we find that companies that provided CSR information before the issuance of regulations exhibit high levels of disclosure. Nevertheless, the coefficient on the interaction term Voluntary_ Post is statistically not significant.

The same evidence reported for CSR disclosure as a whole also occurs when we consider only social disclosure as our dependent variable (Column 3). Indeed, the coefficient of Post is positive and significant, the coefficient on Voluntary is positive and statistically significant, and the coefficient on Mandatory is negative but not statistically significant. Notably, in this latter case, we also report a negative and significant coefficient on the interaction term Voluntary_Post. This evidence, together with the result of the joint test of significance of the coefficients $b_{3}+b_{4}$, suggests that although there was a general increase in the level of social information provided by the sampled companies, after the introduction of regulations, voluntary reporters tended to adjust their disclosures downward and reported social information at lower rates than they did previously.

Conversely, when we use environmental disclosure as our dependent variable, we find slightly different results (Column 2). While the regression result for mandatory reporters echoes the trend previously shown for the overall disclosure score, for the voluntary disclosers, we do not find evidence that their level of environmental disclosure changed after the introduction of mandatory rules and regulations. Column (4) shows that after the issuance of the regulations, ASEAN companies also reported more on the other CSR dimensions. Taken together, our results suggest that 'stick' incentives (in the form of new CSR disclosure requirements) had only a weak effect in ASEAN countries; this effect was different in the mandatory setting (Indonesia and Malaysia) and the voluntary setting (early Indonesian and Malaysian reporters and companies in other countries).

When we examine the relationship between CSR disclosure and 'carrot' incentives, we find consistent support for $\mathrm{H} 2$, as the coefficient on Awards is positive and highly significant across all 
four columns. Hence, our analysis also reveals that there are other legitimacy factors at play that drive the disclosure of CSR information. Indeed, our evidence is aligned with arguments that organizations tend to increase their CSR disclosure to obtain awards for good CSR practices and hence reduce the legitimacy gap between the firm and society.

With respect to control variables, we note that in line with prior literature (Michelon and Parbonetti, 2012; Mallin et al., 2013) the presence of CSR Committee (CSR_Comm) is positive and significant. In addition, membership to environmentally sensitive $(E S I)$ industry positively influences disclosure supporting a legitimacy interpretation. Conversely, Size, Lev and ROE are almost not significant, most likely because firms in the sample are relatively big and profitable and there is little variation in size. Furthermore, the positive and significant coefficient on Status reveals that the private vs. public status has a significant effect on the level of CSR disclosure.

To explore our results in more depth, we conduct additional analyses. First, we acknowledge that the effect of 'stick' incentives depends not only on the introduction of regulations per se but also on the level of enforcement of these regulations. Hence, we perform additional analyses to assess whether the effect of 'stick' (and 'carrot') incentives varies with the enforcement of rules and regulations. Following La Porta et al. (1998) and Kaufmann et al. (2004), we proxy for the enforcement of rules and regulations by relying on the rule of law index, which measures the overall quality of legal systems. The breakdown of our sample reveals that $41.52 \%$ of firms (98 obs.) are from countries with high levels of enforcement, i.e., Malaysia (44 obs.), Singapore (42 obs.), Cambodia (5 obs.), Vietnam (4 obs.) and Brunei (2 obs). Conversely, lower levels of enforcement are found in Indonesia (62 obs.), the Philippines (42 obs.) and Thailand (35 obs.).

Then, we re-run our model [1] for the two sub-samples of firms with high/low levels of enforcement. The results suggest that in countries with low levels of enforcement, mandatory disclosers have low levels of disclosure, although companies that obtain awards tend to disclose more. On the other hand, in countries with high levels of enforcement, both mandatory and 
voluntary reporters exhibit high levels of disclosure, and the receipt of awards does not affect the level of CSR disclosure, with the only exception being social disclosure.

In a further analysis, we take into account that although we use the GRI as the basis for our comparison, not all of the sampled companies explicitly state that they disclose GRI reports. Indeed, an untabulated analysis shows that $28 \%$ (58 obs.) of our sample firms are non-GRI disclosers. With regard to geographic distribution, we find that $18.87 \%$ of these firms (10 obs.) are from Indonesia, $30.19 \%$ (16 obs.) are from Malaysia, 20.75\% (11 obs.) are from Singapore and 18.87\% (10 obs.) are from Thailand. The remaining $11.31 \%$ are from the Philippines ( 2 obs.), Cambodia (2 obs.) and Brunei (2 obs.). The non-GRI disclosers are mostly small firms operating in the construction (32\%), natural resources \& extractive (18.87\%), and services (18.87\%) industries. Their levels of disclosure are significantly lower than the average companies in the sample. In particular, the average score for overall CSR disclosure (SED) is 0.073 , while the mean value for environmental disclosure (ENVD) is 0.087 , and the score for social disclosure (SOCD) is 0.059 .

When we analyze the changes in disclosure before and after the introduction of regulations for the sub-sample of firms disclosing non-GRI reports, the results show that these changes are not statistically significant. However, focusing on the non-GRI disclosers from Indonesia and Malaysia, we find very different results. Indeed, in the post-regulation period, we observe a significant decrease in the environmental, social and other non-CSR related dimensions of corporate performance. To avoid confounding effects related to the idiosyncratic characteristics of non-GRI disclosers that might drive their disclosure behavior, as a robustness test, we re-ran the regression analysis excluding this sub-sample of firms, and our main findings remain unchanged ${ }^{6}$. The results of these additional analyses (reported to the reviewers) are available upon request, but - for brevity - they are not tabulated here.

\footnotetext{
${ }^{6}$ Our results are also robust to different specifications of the models.
} 


\section{Discussion and conclusions}

Through a comprehensive examination of CSR stand-alone reporting practices across ASEAN countries, this paper contributes to the literature by providing evidence that even in this underexplored area, CSR reporting appears to be driven by legitimacy factors. More specifically, we find that CSR disclosure increased in the entire region, although this increase cannot be univocally attributed to the introduction of regulations in Indonesia and Malaysia ('stick' incentives). This result is partially in line with the studies by, e.g., Frost (2007), Chauvey et al. (2015) and Costa and Agostini (2016), which find regulations to have impacts on disclosure, and unlike, e.g., Larrinaga et al. (2002) and Luque-Vilschesz and Larrinaga (2016). At the same time, we observe that CSR disclosure is a result of a proactive stance by companies engaging with some voluntary initiatives ('carrot' incentives), which in our case is the conferment of CSR awards.

We note, however, that the influence of 'stick' and 'carrot' incentives changes in voluntary and mandatory settings and is also subject to characteristics of each institutional regime. Indeed, we find that companies that began disclosing CSR information only once they were obliged to by regulation generally exhibit a low level of CSR disclosure. This evidence can be explained in light of the flexible nature of the CSR regulations, which did not specify disclosure topics, provide clear guidance on the metrics that firms needed to quantify and disclose, nor stipulate specific sanctions in cases of non-compliance (Delbard, 2008; Ioannou and Serafeim, 2017). The findings from our descriptive analysis nevertheless suggest that the regulations may have impacted choices of disclosure media, as organizations seem to have responded by decreasing their disclosure in CSR reports and increasing it in annual reports. Our findings confirm studies (e.g., Costa and Agostini, 2016; Bebbington and Thy, 1999) reporting that the introduction of regulations is viewed more as an administrative reform than as an institutional change when it is not accompanied by a strong stakeholder engagement process (from our qualitative reading of the reports, we indeed have no evidence that such an engagement process occurred). Our findings also echo those of studies from 
Western countries such as France (Delbard 2008) and Spain (Larrinaga et al., 2002), which report low levels of compliance. This highlights the importance that CSR regulations meet the so-called 'test of legitimacy' in order to achieve an increased level of normativity over time (Bebbington et al., 2012; Chauvey et al., 2015).

Conversely, companies that were already reporting voluntarily show high disclosure levels, although such disclosure seems to have been adjusted downward by the introduction of the regulations (with particular regard to social information). This result can be interpreted in two ways. On one hand, companies in Indonesia and Malaysia might have anticipated the legislation and started reporting earlier, which would be consistent with prior findings in the IFRS literature (Daske et al., 2008). On the other hand, there may also be some idiosyncratic characteristics of the companies sampled (with respect to, e.g., culture, size, or industry) that may determine their overall disclosure and particularly their CSR disclosure decisions. This interpretation is in line with the literature on reporting incentives, which argues that it is individual incentives rather than disclosure regulations per se that affect organizational responses to regulation (Leuz, 2010).

Furthermore, our results show that the influence of 'stick' incentives depends on the quality of the regulatory regime in which the company operates. Notably, we find that the introduction of CSR regulations, even broadly stated, can have a positive impact on CSR disclosure in mandatory settings with an effective enforcement environment, which may ensure the correct application of the regulations and lead companies to use CSR disclosures as a means of obtaining legitimacy. This evidence also corroborates the normativity arguments that "formal legislation alone may not be sufficient to create a norm" (Bebbigton et al., 2012 p. 90) by showing that even in settings where informal rules tend to prevail over formal rules (as is largely the case in the ASEAN region), normativity can be achieved through enforcement by a coercive state.

Finally, although we find that 'carrot' incentives usually exert a positive effect on the level of CSR disclosure, we also observe that they matter more in settings characterized by a lower-quality legal 
regime than they do in settings with higher quality. This result adds to the prior literature on Malaysia (Haniffa and Cooke, 2005; Amran and Haniffa, 2011; Anas et al., 2015) suggesting that voluntary initiatives established over time in the ASEAN region can be effective in fostering the provision of CSR information. However, we caution against an interpretation that a higher quantity of CSR disclosure is a synonym for better "quality". Indeed, anecdotal evidence reveals that sometimes firms can be awarded for their CSR practices by governments but then some of their CSR practices are also denounced by NGOs. Likewise, Cho et al. (2012) note that firms that are members of the Dow Jones Sustainability Index (effectively, a CSR award) are worse environmental performers compared to their counterparts. In the context of our research, this might suggest that an increased level of disclosure does not necessarily reflect higher quality or better performance. Indeed, the noted initial reluctance of organizations to report on issues such as child labor, human rights and corruption as well as the shift of negative information from annual reports to CSR reports suggests the existence of opportunistic disclosure strategies that deviate from the underlying CSR performance (i.e., impression management, Shrives and Brennan, 2016).

Our overall findings confirm the theoretical arguments that companies engage in CSR reporting in response to institutional pressures (Meyer and Rowan, 1977) and support the view that disclosure is mainly used proactively to obtain the associated economic benefits, which is consistent with the strategic legitimacy perspective (Clikeman, 2004). However, we contribute to this stream of literature by additionally observing that the way companies use CSR disclosure to attain legitimacy is shaped by the characteristics of the institutional setting. Our results suggest that on one hand, organizations have more room to impact their legitimacy strategically in settings characterized by low-quality legal systems. On the other hand, organizations place more emphasis on the process of institutionalization when the regulatory regime imposes strict sanctions on companies that fail to comply with societal expectations. 
In that respect, our results have important implications. Our evidence can inform standard setters and capital market regulators in their deliberations regarding whether they should mandate CSR disclosures. Despite the overall low disclosure breadth observed (particularly for the performance indicators), the results encourage the issuance of new (and even broadly stated) regulations that mandate CSR reporting. Our results also call for effective regulatory institutions to enforce the application of these regulations, regardless of the type of regulation introduced. In this vein, our study is informative not only for the ASEAN region but also for other Western economies characterized by similar socio-political and cultural environments for highlighting the importance of a culture of law enforcement in achieving a high level of transparency in CSR disclosure.

We acknowledge that the study also suffers from limitations, which nevertheless open avenues for future research. First, as anticipated earlier in the manuscript, our choice of measures (disclosure level and disclosure breadth) does not allow us to ascertain whether the reported increase in CSR disclosure reflected a company's commitment to be transparent rather than an impression management strategy. Future studies could further explore CSR disclosure in the ASEAN region by examining the informational attributes of disclosure and their influences. Second, although our analysis of the effect of the regulations is consistent with the well-established literature (Daske et al., 2008; Horton et al., 2013), the peculiarities of the setting under investigation and the explorative nature of our study prohibited the use of a control group to be used as a benchmark for our sample. Further research could analyze the effect of the regulations in Malaysia and Indonesia using a difference-in-differences research design and track CSR disclosure changes from one year to another. Third, we examine the level of, and the motivation for, CSR disclosure in the standalone reports of ASEAN companies. While we also provide an examination of CSR information in the annual reports of sampled companies at the univariate level, our analysis does not consider other website disclosures, which could also be the focus of future research. 


\section{References}

ACCA (Association of Chartered Certified Accountants) (2004), "Report Summary: The State of Corporate Environmental and Social Reporting in Malaysia 2004" [pdf], Availableat: http://www2.accaglobal.com/documents/malaysian_state_of_ser2004.pdf (Accessed 21 May 2013).

ACCA (Association of Chartered Certified Accountants) (2010), "Sustainability Reporting: The Rise of the Report and the Regulator" [pdf], Available at: http://www2.accaglobal.com /documents/sustainabilityreportingfutur.pdf (Accessed 2 November 2012).

Adams, C.A., Coutts ,A. and Harte, G. (1995), "Corporate equal opportunities (non) disclosure", British Accounting Review, Vol. 27, pp. 87-108.

Amran, A. and Haniffa, R. (2011), "Evidence in development of sustainability reporting: a case of a developing country”, Business Strategy and the Environment, Vol. 120, pp. 141-156.

Anas, A., Rashid, H.M.A. and Annuar, H.A. (2015), "The effect of award on CSR disclosures in annual reports of Malaysian PLCs", Social Responsibility Journal, Vol. 11, No. 4, pp. 831-852.

Andrew, B.H., Gul, F.A., Guthrie, J.E. and Teoh, H.Y. (1989), "A note on corporate social disclosure practices in developing countries: the case of Malaysia and Singapore", British Accounting Review, Vol. 21, pp. 371-376.

Ang, S.H. and Leong, S.M. (2000), "Out of the mouths of babes: Business ethics and youths in Asia”, Journal of Business Ethics, Vol. 28, No. 2, pp. 129-144.

Arena, C., Bozzolan, S., and Michelon, G. (2015), "Environmental reporting: Transparency to stakeholders or stakeholder manipulation?", Corporate Social Responsibility and Environmental Management, Vol. 22, No. 6, pp. 346-361.

Baughn, C., Bodie, N.. and McIntosh, J. (2007), "Corporate Social and Environmental Responsibility in Asian Countries and Other Geographical Regions", Corporate Social Responsibility and Environmental Management, Vol. 14, pp. 189-205.

Bebbington, J., Kirk, E. and Larrinaga, C. (2012), "The production of normativity: a comparison of reporting regimes in Spain and the UK”, Accounting, Organizations and Society, Vol. 37, pp. 7894.

Bebbington, J. and Thy, C. (1999), "Compulsory environmental reporting in Denmark: an evaluation", Social and Environmental Accountability Journal, Vol. 19, No. 2, pp. 2-4.

Boesso, G. and Kumar, K. (2007), "Drivers of corporate voluntary disclosure: a framework and empirical evidence from Italy and the United States", Accounting, Auditing and Accountability Journal, Vol. 20, No. 2, pp. 111-122.

Boiral, O. (2013), "Sustainability reports as simulacra?.A counter-account of A and A+ GRI reports”, Accounting Auditing and Accountability Journal, Vol. 26, No. 7, pp. 1036-1071. 
Bouten, L., Everaert, P., Liedekerke, L., Moor L. and Christiaens J. (2011), "Corporate Social Responsibility Reporting: A Comprehensive Picture?", Accounting Forum, Vol. 35, No. 3, pp. 187204.

Brammer, S., and Pavelin, S. (2008), "Factors influencing the quality of corporate environmental disclosure", Business Strategy and the Environment, Vol. 17, No. 2, pp. 120-136.

Cahaya, F.R., Porter, S.A., Tower, G. and Brown, A. (2012), "Indonesia's low concern for labour issues", Social Responsibility Journal, Vol. 8, No. 1, pp. 114-132.

Chapple, W. and Moon, J. (2005), "Corporate Social Responsibility (CSR) in Asia: A seven country study of CSR website reporting", Business and Society, Vol. 44, No. 4, pp. 415-41.

Chapple, W. and Moon, J. (2007), "Introduction: CSR Agendas for Asia", Corporate Social Responsibility and Environmental Management, Vol. 14, pp. 183-188.

Chauvey, J., Giordano-Spring, S., Cho, C. and Patten, D. (2015), "The normativity and legitimacy of CSR disclosure: evidence from France”, Journal of Business Ethics, Vol. 130, pp. 789-803.

Chen, J.C. and Roberts, R.W. (2010), "Towards a more coherent understanding of the organizationsociety relationship", Journal of Business Ethics, Vol. 97, pp. 651-665.

Cho, C. and Patten, D. (2007), "The role of environmental disclosures as tools of legitimacy: a research note", Accounting, Organizations and Society, Vol. 32, No. 7-8, pp. 639-647.

Cho, C., Patten, D., and Roberts, R.W. (2006), "Corporate political strategy: An examination of the relation between political expenditures, environmental performance, and environmental disclosure", Journal of Business Ethics, Vol. 67, No. 2, pp. 139-154.

Cho, C., Michelon, G. and Patten, D. (2012), "Enhancement and obfuscation through the use of graphs in sustainability reports", Sustainability Accounting, Management and Policy Journal, Vol. 3, No. 1, pp. 74:88.

Clikeman, P.M. (2004), "Socially conscious corporation: how can you reap the rewards of good corporate citizenry?" Strategic Finance, Vol. 85, No. 10, pp. 23-27.

Costa, E. and Agostini, M. (2016), "Mandatory disclosure about environmental and employee matters in the reports of Italian-listed corporate groups", Social and Environmental Accountability Journal, Vol. 36, No. 1, pp. 10-33.

Criado-Jimenez, I., Fernandez-Chulian, M., Husillos-Carques, F.J. and Larrinaga-Gonzalez, C. (2008), "Compliance with mandatory environmental reporting in financial statements: the case of Spain”, Journal of Business Ethics, Vol. 79, pp. 245-262.

Daske, H., Hail, L., Leuz, C. and Verdi, R. (2008), "Mandatory IFRS reporting around the world", Journal of Accounting Research, Vol. 46, pp. 1085-1142. 
Day, R. and Woodward, T. (2004), "Disclosure of information about employees in the Directors' report of UK published financial statements: substantive or symbolic?" Accounting Forum, Vol. 28, pp. 45-39.

Deegan, C. (2000), Financial Accounting Theory, McGraw Hill Book Company, Sydney.

Deegan, C. and Carroll, G. (1993), “An analysis of the incentives for Australian firms to apply for reporting excellence awards", Accounting and Business Research, Vol. 15, No. 2, pp. 312-343.

Deegan, C., and Gordon, B. (1996), "A study of the environmental disclosure practices of Australian corporations", Accounting and Business Research, Vol. 26, No. 3, pp. 187-199.

Delbard, O. (2008), "CSR legislation in France and the European regulatory paradox", Corporate Governance, Vol. 8, No. 4, pp. 397-405.

DiMaggio, P.J. and Powel, W. (1983), “The iron cage revisited: institutional isomorphism and collective rationality in organizational fields", American Sociological Review, Vol. 48, pp. 147-160.

Djajadikerta, H.G. and Trireksani, T. (2012), "Corporate social and environmental disclosure by Indonesian listed companies on their corporate websites", Journal of Applied Accounting Research, Vol. 13, No. 1, pp. 21-36.

Dowling, J. and Pfeffer, J. (1975), “Organizational legitimacy: social values and organizational behaviour”, Pacific Sociological Review, Vol. 18, No. 1, pp. 122 - 136.

Fallan, E. (2016), "Environmental reporting regulations and reporting practices", Social and Environmental Accountability Journal, Vol. 36, pp. 34-55.

Fallan, E., and Fallan, L. (2009), "Voluntarism versus regulation: lessons from public disclosure of environmental performance information in Norwegian companies." Journal of Accounting \& Organizational Change, Vol. 5, No. 4, pp. 472-489.

Fifka, M.S. (2012), "The development and state of research on social and environmental reporting in global comparison”, Journal für Betriebswirtschaft, Vol. 62, No. 1, pp. 45-84.

Forbes, S. and McIntosh, M. (2011), "Towards CSR and the sustainable enterprise economy in the Asia Pacific Region", Sustainability Accounting, Management and Policy Journal, Vol. 2, No. 2, pp. 194-213.

Freedman, M. and Stagliano, A.J. (2008), “Accountability and emissions allowance trading”, Social and Environmental Accountability Journal, Vol. 28, No. 2, pp. 62-77.

Frost, G.R. (2007), "The introduction of mandatory environmental reporting guidelines: Australian evidence", Abacus, Vol. 43, No. 2, pp. 190-216.

Global Reporting Initiative (GRI), (2002), Sustainability reporting guidelines, GRI, Boston.

Global Reporting Initiative (GRI), (2013), "Report or Explain Campaign Forum”, available at: https://www.globalreporting.org/network/report-or-explain/Pages/default.aspx (accessed 28 May 2013). 
Graafland, J. and Smid, H. (2016), "Decoupling among CSR policies, programs, and impacts: an empirical study”, Business \& Society, pp. 1-37, DOI: 10.1177/0007650316647951.

Gray, R., Kouhy, R. and Lavers, S. (1995), "Corporate social and environmental reporting: a review of the literature and a longitudinal study of UK disclosure", Accounting, Auditing and Accountability Journal, Vol. 8, No. 2, pp. 47-77.

Gray, R., Owen, D. and Adams, C. (2010), "Some theories for social accounting?: A review essay and a tentative pedagogic categorisation of theorisations around social accounting", Advances in Environmental Accounting and Management, Vol. 4, pp. 1-54.

Gunawan, J. (2007), "Corporate social disclosures by Indonesian listed companies: a pilot study", Social Responsibility Journal, Vol. 3, No. 3, pp. 26-34.

Gunawan, J. (2010), "Perception of important information in corporate social disclosures: evidence from Indonesia”, Social Responsibility Journal, Vol. 6, No. 1, pp. 62-71.

Gunawan, J. (2015), “Corporate social disclosures in Indonesia: stakeholders' influence and motivation”, Social Responsibility Journal, Vol. 11, No. 3, pp. 535-552.

Guthrie, J.E. and Parker, L.D. (1989), "Corporate social reporting: a rebuttal of legitimacy theory", Accounting and Business Research, Vol. 9, No. 76, pp. 343-352.

Haji, A.A. (2013), "Corporate social responsibility disclosures over time: evidence from Malaysia", Managerial Auditing Journal, Vol. 28, No. 7, pp. 647-676.

Haniffa, R.M. and Cooke, T.E. (2005), "The impact of culture and corporate governance on corporate social reporting", Journal of Accounting and Public Policy, Vol. 24, No. 5, pp. 391-430.

Horton, J., Serafeim, G., and Serafeim, I. (2013), "Does mandatory IFRS adoption improve the information environment?", Contemporary Accounting Research, Vol. 30, No. 1, pp. 388-423.

Ioannou, I. and Serafeim, G. (2014), "The consequences of mandatory corporate sustainability reporting”, Harvard Business School Research Working Paper No. 11-100.

Ioannou, I. and Serafeim, G. (2017), “The consequences of mandatory corporate sustainability reporting”, available at SSRN: https://papers.ssrn.com/sol3/papers.cfm?abstract_id=1799589.

IRI (Initiative for Responsible Investment), (2012), Current Corporate Social Responsibility Disclosure Efforts by National Governments and Stock Exchanges, The Hauser Center for Nonprofit Organization, Harvard University, Cambridge, MA.

Jamil, C.Z.M., Alwi, K. and Mohamed, R. (2002), "Corporate social responsibility disclosure in the annual reports of Malaysian companies: a longitudinal study", Social and Environmental Accountability Journal, Vol. 22, No. 2, pp. 5-9.

Kaufmann, D., Kraay, A. and Mastruzzi, M. (2004), "Governance Matters III: Governance Indicators for 1996, 1998, 2000, and 2002”, World Bank Economic Review, Vol. 18, pp. 253-287. 
Kimber, D. and Lipton, P. (2005), "Corporate governance and business ethics in the Asia-Pacific region”, Business and Society, Vol. 44, No. 2, pp. 178-210.

KPMG (2016), "Carrots \& Sticks: global trends in sustainability reporting regulation and policy", [pdf], Available at: www.carrotsandsticks.net (Accessed 19 May 2017).

Kuasirikun, N. (2011), "The portrayal of gender in annual reports in Thailand", Critical Perspectives on Accounting, Vol. 22, pp. 53-78.

Kuasirikun, N. and Sherer, M. (2004), "Corporate social accounting disclosure in Thailand", Accounting, Auditing \& Accountability Journal, Vol. 17, No. 4, pp. 629-660.

La Porta, R., Lopez-de-Silanes, F., Shleifer, A. and Vishny, R.W. (1998), "Law and Finance", Journal of Political Economy, Vol. 106, Vol. 6, pp. 1113-1155.

Landis, J. R., and Koch, G.G. (1977), “The measurement of observer agreement for categorical data", Biometrics, pp. 159-174.

Larrinaga, C., Carrasco, F., Correa, C., Llena, F. and Moneva, J.M. (2002), “Accountability and accounting regulation: the case of the Spanish environmental disclosure standard", The European Accounting Review, Vol. 11, No. 4, pp. 723-740.

Larrinaga-Gonzalez, C. (2007), "Sustainability reporting: insights from neo-institutional theory", in Unerman, J., Bebbington, J. and O'Dwyer, B. (Eds), Sustainability, Accounting and Accountability, Routledge, London, pp. 150-167.

Le, T.T.T. (2011), Corporate Social Responsibility Reporting In Large Listed Vietnamese Companies, BBA, Lahti University Of Applied Sciences, Lahti.

Leuz, C. (2010), "Different approaches to corporate reporting regulation: how jurisdictions differ and why", Accounting and Business Research, Vol. 40, No. 3, pp. 229-256.

Lindblom, C.K. (1993), "The implications of organizational legitimacy for corporate social performance and disclosure", paper presented at the Critical Perspectives on Accounting Conference, New York.

Liu, X., and Anbumozhi, V. (2009), "Determinant factors of corporate environmental information disclosure”, Journal of Cleaner Production, Vol. 17, No. 6, pp. 593-600.

Llena, F., Moneva, J.M. and Hernandez, B. (2007), "Environmental disclosures and compulsory accounting standards", Business Strategy and the Environment, Vol. 16, pp. 50-63.

Lodhia, S.K. (2012), “Corporate social responsibility/sustainability regulation”, in Jones, S. and Ratnatunga, J (Eds), Contemporary issues in sustainability accounting, assurance and reporting, Emerald, Bingley.

Luque-Vilchez, M. and Larrinaga, C. (2016), "Reporting models do not translate well", Social and Environmental Accountability Journal, Vol. 36, No. 1, pp. 56-75. 
Mahoney, L. S., Thorne, L., Cecil, L., and LaGore, W. (2013), “A research note on standalone corporate social responsibility reports: Signaling or greenwashing?", Critical Perspectives on Accounting, Vol. 24, No. 4-5, pp. 350-359.

Mallin, C.A. and Michelon, G. (2011), "Board reputation attributes and corporate social performance", Accounting and Business Research, Vol. 41, No. 2, pp. 119-144.

Mallin, C.A., Michelon, G. and Raggi, D. (2013), "Monitoring intensity and stakeholders' orientation: how does governance affect social and environmental disclosure?", Journal of Business Ethics, Vol. 114, No. 1, pp. 29-43.

Meyer, J.W. and Rowan, B. (1977), "Institutionalized organizations: formal structure as myth and ceremony”, American Journal of Sociology, Vol. 83, No. 2, pp. 340-63.

Michelon, G. and Parbonetti, A. (2012), "The effect of corporate governance on sustainability disclosure", Journal of Management and Governance, Vol. 16, pp. 477-509.

Michelon, G., Pilonato, S., Ricceri, F. (2015), "CSR reporting practices and the quality of disclosure: An empirical analysis”, Critical Perspectives on Accounting, Vol. 33, pp. 59-78.

Milne, M.J. and Adler, R.W. (1999), "Exploring the reliability of social and environmental disclosures content analysis", Accounting, Auditing and Accountability Journal, Vol. 12, No. 2, pp. 237-256.

Mirfazli, E. (2008), "Evaluate corporate social responsibility disclosure at annual report companies in multifarious group of industry members of Jakarta Stock Exchange (JSX), Indonesia", Social Responsibility Journal, Vol. 4, No. 3, pp. 388-406.

Mobus, J.L. (2005), "Mandatory environmental disclosures in a legitimacy theory context", Accounting, Auditing and Accountability Journal, Vol. 18, No. 4, pp. 492-517.

Patten, D.M. (1992), "Intra-industry environmental disclosures in response to the Alaskan oil spill: a note on legitimacy theory”, Accounting, Organizations and Society, Vol. 17, No. 5, pp. 471-475.

Patten, D.M. and Trompeter, G. (2003), "Corporate responses to political costs", Journal of Accounting and Public Policy, Vol. 22, No. 1, pp. 83-94.

Perry, M., and Tse Sheng, T. (1999), “An overview of trends related to environmental reporting in Singapore”, Environmental Management and Health, Vol. 10, No. 5, pp. 310-320.

Peteres, G.F. and Romi, A.M. (2013), "Discretionary compliance with mandatory environmental disclosures: evidence from SEC filings", Journal of Accounting and Public Policy, Vol. 32, pp. 213-236.

Ramasamy, B. and Ting, W.T. (2004), “A comparative analysis of corporate social responsibility awareness", Journal of Corporate Citizenship, Vol. 13, pp. 109-123.

Ratanajongkol, S., Davey, H. and Low, M. (2006), "Corporate social reporting in Thailand", Qualitative Research in Accounting \& Management, Vol. 3, No. 1, pp. 67-83. 
Ryan, C., Dunstan, K. and Brown, J. (2002), 'The value of public sector annual reports and annual reporting awards in organisational legitimacy', Accounting, Accountability \& Performance, Vol. 8, No. 1, pp. 61-76.

Saleh, M. (2009), "Corporate social responsibility disclosure in an emerging market: a longitudinal analysis approach”, International Business Research, Vol. 2, No. 1, pp. 131-141.

Sawani, Y., Zain, M.M. and Darus, F. (2010), "Preliminary insights on sustainability reporting and assurance practices in Malaysia”, Social Responsibility Journal, Vol. 6, No. 4, pp. 627-645.

Spence, C., Husillos, J. and Correa-Ruiz, C. (2010), "Cargo cult science and the death of politics", Critical Perspectives on Accounting, Vol. 21, pp. 76-89.

Suchman, M. (1995), "Managing legitimacy: strategic approaches and institutional approaches", Academy of Management Review, Vol. 20, No. 3, pp. 571-610.

Teoh, H.Y. and Thong, G. (1984), “Another Look at Corporate Social Responsibility and Reporting”, Accounting, Organizations and Society, Vol. 9, No. 2, pp. 189-206.

Thompson, P. and Zakaria, Z. (2004), "Corporate social responsibility reporting in Malaysia: progress and prospects”, Journal of Corporate Citizenship, Vol. 13, pp. 125-136.

Tsang, E.W.K. (1998), "A longitudinal study of corporate social reporting in Singapore", Accounting, Auditing \& Accountability Journal, Vol. 11, No. 5, pp. 624-635.

Visser, W. (2011), The Age of Responsibility: CSR 2.0 and the New DNA of Business, Wiley, Chichester.

Vourvachis, P. and Woodward, T. (2015), "Content analysis in social and environmental reporting research: trends and challenges”, Journal of Applied Accounting Research, Vol. 16, pp. 166-195.

Vourvachis, P., Woodward, T., Woodward, D. and Patten, D. (2016), "Disclosure reactions to major accidents: insights from the aviation industry", Sustainability Accounting, Management and Policy Journal, Vol. 7, No. 1, pp. 26-43.

Weber, O. (2014), "Environmental, social and governance reporting in China”, Business Strategy and the Environment, Vol. 23, pp. 303-317.

Welford, R. (2004), “Corporate Social Responsibility in Europe and Asia", Journal of Corporate Citizenship, Vol. 13, pp. 31-47.

Welford, R. (2005), "Corporate social responsibility in Europe, North America and Asia”, Journal of Corporate Citizenship, Vol. 17, pp. 33-52.

Williams, A.M. and Pei, C.A.H. (1999), "Corporate social disclosures by listed companies on their web-sites”, The International Journal of Accounting, Vol. 34, No. 3, pp. 389-419.

Young, S.T. and Dhanda, K.K. (2013), Sustainability: essentials for business, Sage, Thousand Oaks, CA. 
Table 1. Descriptive statistics for continuous variables

\begin{tabular}{lllllllll}
\hline & $\boldsymbol{N}$ & mean & $\boldsymbol{m i n}$ & $\boldsymbol{p 2 5}$ & $\boldsymbol{p 5 0}$ & $\boldsymbol{p 7 5}$ & max & sd \\
\hline SED & 236 & 0.379 & 0 & 0.146 & 0.302 & 0.629 & 0.991 & 0.299 \\
ENVD & 236 & 0.394 & 0 & 0.144 & 0.367 & 0.568 & 1 & 0.307 \\
SOCD & 236 & 0.364 & 0 & 0.082 & 0.259 & 0.653 & 1 & 0.314 \\
OTHER & 236 & 0.777 & 0.216 & 0.664 & 0.824 & 0.927 & 1 & 0.118 \\
Award & 236 & 17.478 & 0 & 5 & 11 & 22 & 120 & 19.534 \\
Media & 236 & 968.817 & 0 & 155.500 & 428.500 & 1030.500 & 9788 & 1459.995 \\
Size & 236 & 28.015 & 16.538 & 22.615 & 27.645 & 30.177 & 42.738 & 6.725 \\
Lev & 236 & 1.894 & 0.358 & 0.614 & 1.167 & 1.922 & 6.657 & 1.995 \\
ROE & 236 & 0.167 & 0.040 & 0.084 & 0.146 & 0.232 & 0.361 & 0.101 \\
\hline
\end{tabular}

See Appendix 4 for variable definitions.

Table 2. Distribution of CSR Awards by country and type

\begin{tabular}{rccccccc}
\hline \multirow{2}{*}{ Country } & CSR & Reporting Awards & Monetary Awards & Other Awards \\
& Awards & & & & & & \\
& Not & No CSR & CSR Index & No $R$ & CSR & No CSR & CSR \\
& & Index & & Index & Index & Index & Index \\
\hline Indonesia & 19.483 & 1.050 & 0.500 & 0.000 & 0.000 & 18.667 & 13.000 \\
Malaysia & 17.659 & 0.645 & 4.923 & 0.000 & 2.769 & 12.838 & 21.692 \\
Philippines & 10.121 & 0.461 & 0.000 & 0.000 & 0.000 & 9.384 & 13.500 \\
Singapore & 18.952 & 0.687 & 1.000 & 0.125 & 0.000 & 16.593 & 22.900 \\
Thailand & 25.742 & 0.857 & - & 0.000 & - & 24.914 & - \\
Others & 2.333 & 0.083 & - & 0.000 & - & 2.250 & - \\
\hline
\end{tabular}




\section{Table 3. Disclosure scores by country}

\begin{tabular}{|c|c|c|c|c|c|c|c|c|c|c|c|}
\hline Country & Statistics & Str & OP & $\mathbf{R P}$ & Eco_D & Gov_D & Env_D & Lab_D & HR_D & So_D & Prod_D \\
\hline \multirow[t]{3}{*}{ Indonesia } & mean & 0.939 & 0.924 & 0.785 & 0.627 & 0.747 & 0.500 & 0.571 & 0.384 & 0.447 & 0.461 \\
\hline & $\min$ & 0.500 & 0.400 & 0.150 & 0.000 & 0.030 & 0.000 & 0.000 & 0.000 & 0.000 & 0.000 \\
\hline & $\max$ & 1.000 & 1.000 & 1.000 & 1.000 & 1.000 & 1.000 & 1.000 & 1.000 & 1.000 & 1.000 \\
\hline \multirow[t]{3}{*}{ Malaysia } & mean & 0.161 & 0.160 & 0.261 & 0.328 & 0.323 & 0.366 & 0.332 & 0.370 & 0.330 & 0.431 \\
\hline & $\min$ & 0.500 & 0.900 & 0.308 & 0.000 & 0.059 & 0.000 & 0.000 & 0.000 & 0.000 & 0.000 \\
\hline & $\max$ & 1.000 & 1.000 & 1.000 & 1.000 & 1.000 & 1.000 & 1.000 & 1.000 & 1.000 & 1.000 \\
\hline \multirow[t]{3}{*}{ Philippines } & mean & 0.829 & 0.986 & 0.916 & 0.465 & 0.773 & 0.399 & 0.521 & 0.228 & 0.273 & 0.341 \\
\hline & $\min$ & 0.250 & 0.875 & 0.636 & 0.222 & 0.353 & 0.000 & 0.000 & 0.000 & 0.000 & 0.000 \\
\hline & $\max$ & 1.000 & 1.000 & 1.000 & 1.000 & 1.000 & 1.000 & 1.000 & 0.909 & 0.900 & 1.000 \\
\hline \multirow[t]{3}{*}{ Singapore } & mean & 0.988 & 0.971 & 0.862 & 0.383 & 0.764 & 0.388 & 0.392 & 0.176 & 0.291 & 0.294 \\
\hline & $\min$ & 0.500 & 0.800 & 0.308 & 0.111 & 0.118 & 0.000 & 0.000 & 0.000 & 0.000 & 0.000 \\
\hline & $\max$ & 1.000 & 1.000 & 1.000 & 0.889 & 1.000 & 0.896 & 1.000 & 0.800 & 0.800 & 1.000 \\
\hline \multirow[t]{3}{*}{ Thailand } & mean & 0.835 & 0.892 & 0.724 & 0.438 & 0.673 & 0.430 & 0.449 & 0.305 & 0.402 & 0.420 \\
\hline & $\min$ & 0.000 & 0.300 & 0.269 & 0.000 & 0.000 & 0.000 & 0.000 & 0.000 & 0.000 & 0.000 \\
\hline & $\max$ & 1.000 & 1.000 & 1.000 & 1.000 & 1.000 & 1.000 & 1.000 & 1.000 & 1.000 & 1.000 \\
\hline \multirow[t]{3}{*}{ Others } & mean & 0.812 & 1.000 & 0.703 & 0.215 & 0.431 & 0.105 & 0.149 & 0.060 & 0.104 & 0.046 \\
\hline & $\min$ & 0.500 & 1.000 & 0.333 & 0.111 & 0.176 & 0.000 & 0.000 & 0.000 & 0.000 & 0.000 \\
\hline & $\max$ & 1.000 & 1.000 & 1.000 & 0.389 & 0.912 & 0.367 & 0.357 & 0.182 & 0.500 & 0.222 \\
\hline
\end{tabular}

See Appendix 4 for variable definitions. 
Table 4. Mean CSR disclosure scores Pre vs Post

\begin{tabular}{|c|c|c|c|c|c|}
\hline & $n$ & SED & $E N V D$ & SOCD & OTHERD \\
\hline \multicolumn{6}{|c|}{ Panel A: Full sample } \\
\hline Pre & 22 & 0.248 & 0.247 & 0.248 & 0.634 \\
\hline Post & 214 & 0.393 & 0.410 & 0.376 & 0.792 \\
\hline sig. & & 0.029 & 0.018 & 0.068 & 0.000 \\
\hline \multicolumn{6}{|c|}{ Panel B: Sub-sample Indonesia and Malaysia } \\
\hline Pre & 14 & 0.332 & 0.302 & 0.362 & 0.714 \\
\hline Post & 92 & 0.434 & 0.433 & 0.434 & 0.816 \\
\hline sig. & & 0.304 & 0.194 & 0.485 & 0.062 \\
\hline
\end{tabular}

See Appendix 4 for variable definitions.

Significance levels are two-tailed.

Table 5. Mean CSR disclosure scores 2006 vs 2007

\begin{tabular}{llllll}
\hline & $\boldsymbol{n}$ & $\boldsymbol{S E D}$ & $\boldsymbol{E N V D}$ & SOCD & OTHERD \\
\hline Panel A: Total sample & \multicolumn{5}{l}{} \\
\hline 2006 & 10 & 0.248 & 0.266 & 0.229 & 0.631 \\
2007 & 21 & 0.250 & 0.311 & 0.189 & 0.623 \\
sig. & 0.981 & 0.670 & 0.675 & 0.921 \\
\hline \multicolumn{5}{l}{ Panel B: Sub-sample Indonesia and Malaysia } \\
2006 & 7 & 0.293 & 0.280 & 0.306 & 0.723 \\
2007 & 11 & 0.263 & 0.283 & 0.242 & 0.663 \\
sig. & 0.844 & 0.988 & 0.675 & 0.5771 \\
\hline
\end{tabular}

See Appendix 4 for variable definitions.

Significance levels are two-tailed.

Table 6. Mean scores for Annual Report CSR disclosure

\begin{tabular}{|c|c|c|c|c|c|}
\hline & $n$ & $S E D$ & $E N V D$ & SOCD & OTHERD \\
\hline \multicolumn{4}{|c|}{ Panel A: Indonesia and Malaysia (Pre-Post) } & +2 & \\
\hline Pre & 10 & 0.096 & 0.053 & 0.139 & 0.794 \\
\hline Post & 66 & 0.172 & 0.180 & 0.164 & 0.819 \\
\hline sig. & & 0.001 & 0.001 & 0.217 & 0.150 \\
\hline \multicolumn{6}{|c|}{ Panel B: Indonesia and Malaysia (2006-2007) } \\
\hline 2006 & 5 & 0.103 & 0.073 & 0.134 & 0.781 \\
\hline 2007 & 4 & 0.187 & 0.229 & 0.146 & 0.804 \\
\hline sig. & & 0.030 & 0.035 & 0.710 & 0.495 \\
\hline
\end{tabular}

See Appendix 4 for variable definitions.

Significance levels are two-tailed. 
Table 7. Average scores of CSR disclosure items between the years

\begin{tabular}{|c|c|c|c|c|c|}
\hline \multirow{2}{*}{$\begin{array}{l}\text { GRI } \\
\text { Ref. }\end{array}$} & \multirow{2}{*}{ CSR information } & \multicolumn{2}{|c|}{ Annual Report } & \multicolumn{2}{|c|}{ CSR Report } \\
\hline & & 2006 & 2007 & 2006 & 2007 \\
\hline & Strategy, profile and governance & & & & \\
\hline 1.2 & Description of key impacts, risks and opportunities & 1.000 & 1.000 & 0.857 & 0.727 \\
\hline 2.3 & Operational structure of the organisation & 0.800 & 1.000 & 0.857 & 0.818 \\
\hline 3.7 & Boundaries of the report & 0.800 & 1.000 & 0.500 & 0.455 \\
\hline 3.13 & Policy on seeking external assurance & 1.000 & 1.000 & 0.286 & 0.182 \\
\hline 4.4 & Mechanisms for employee and shareholder feedback & 0.800 & 0.750 & 0.714 & 0.636 \\
\hline 4.5 & Link of executive remuneration to performance & 0.800 & 0.750 & 0.571 & 0.455 \\
\hline 4.14 & List of stakeholder groups engaged & 0.300 & 0.750 & 0.571 & 0.545 \\
\hline 4.15 & Basis for identification of stakeholders & 0.100 & 0.500 & 0.571 & 0.455 \\
\hline \multirow[t]{2}{*}{4.16} & Frequency of stakeholder engagement & 0.400 & 0.750 & 0.571 & 0.500 \\
\hline & Economic performance & & & & \\
\hline EC2 & Financial implications due to climate change & 0.400 & 0.250 & 0.429 & 0.364 \\
\hline EC6 & Spending on locally-based suppliers & 0.400 & 0.625 & 0.286 & 0.364 \\
\hline EC8 & Infrastructure investments for public benefit & 0.800 & 1.000 & 0.714 & 0.636 \\
\hline \multirow[t]{2}{*}{ EC9 } & Indirect economic impacts & 0.600 & 1.000 & 0.571 & 0.182 \\
\hline & Environmental performance & & & & \\
\hline EN1 & Materials used by weight or volume & 0.200 & 0.500 & 0.357 & 0.500 \\
\hline EN7 & Initiatives to reduce indirect energy consumption & 0.200 & 0.750 & 0.286 & 0.273 \\
\hline EN9 & Land owned or managed adjacent to protected areas & 0.200 & 0.500 & 0.571 & 0.409 \\
\hline EN14 & Managing impacts on biodiversity & 0.300 & 0.625 & 0.500 & 0.364 \\
\hline EN18 & Initiatives to reduce greenhouse gas emissions & 0.100 & 0.625 & 0.429 & 0.273 \\
\hline \multirow[t]{2}{*}{ EN26 } & Initiatives to mitigate environmental impacts & 0.400 & 0.875 & 0.286 & 0.182 \\
\hline & Labour practices performance & & & & \\
\hline LA1 & Total workforce by type, contract, region and gender & 0.400 & 0.625 & 0.857 & 0.591 \\
\hline LA2 & Employee turnover by age, group, gender and region & 0.000 & 0.125 & 0.500 & 0.273 \\
\hline LA7 & Rates of injury, occupational diseases and absenteeism & 0.500 & 0.750 & 0.643 & 0.727 \\
\hline LA9 & Health and Safety coverage in agreement with unions & 0.300 & 0.125 & 0.286 & 0.273 \\
\hline LA10 & Employee training per year, gender and category & 0.200 & 0.625 & 0.500 & 0.273 \\
\hline \multirow[t]{2}{*}{ LA12 } & Employee career development & 0.200 & 0.500 & 0.429 & 0.182 \\
\hline & Human rights performance & & & & \\
\hline HR2 & Human rights screening of suppliers & 0.000 & 0.000 & 0.143 & 0.091 \\
\hline HR3 & Employee training on human rights & 0.100 & 0.000 & 0.143 & 0.182 \\
\hline HR5 & Risks to collective bargaining & 0.000 & 0.000 & 0.429 & 0.364 \\
\hline HR6 & Child labour incidents and risks & 0.000 & 0.000 & 0.429 & 0.273 \\
\hline \multirow[t]{2}{*}{ HR7 } & Forced labour incidents and risks & 0.000 & 0.000 & 0.429 & 0.182 \\
\hline & Society performance & & & & \\
\hline SO1 & Local community engagement & 0.800 & 1.000 & 0.786 & 0.864 \\
\hline $\mathrm{SO} 2$ & Business units analysed for risks related to corruption & 0.100 & 0.000 & 0.286 & 0.091 \\
\hline $\mathrm{SO} 3$ & Anti-corruption policies and employee training & 0.100 & 0.000 & 0.429 & 0.182 \\
\hline SO8 & Fines related to non-compliance with laws & 0.400 & 0.250 & 0.143 & 0.273 \\
\hline \multirow[t]{2}{*}{ SO9 } & Operations with negative impacts on communities & 0.200 & 0.000 & 0.000 & 0.091 \\
\hline & Product responsibility performance & & & & \\
\hline PR1 & Health and safety impacts of products and services & 0.400 & 0.250 & 0.214 & 0.182 \\
\hline PR5 & Customer satisfaction practices and surveys & 0.400 & 0.250 & 0.429 & 0.364 \\
\hline PR7 & Non-compliance with marketing codes & 0.000 & 0.000 & 0.286 & 0.273 \\
\hline PR9 & Fines related to non-compliance with product laws & 0.000 & 0.000 & 0.286 & 0.273 \\
\hline
\end{tabular}


Table 8. Test of Hypotheses

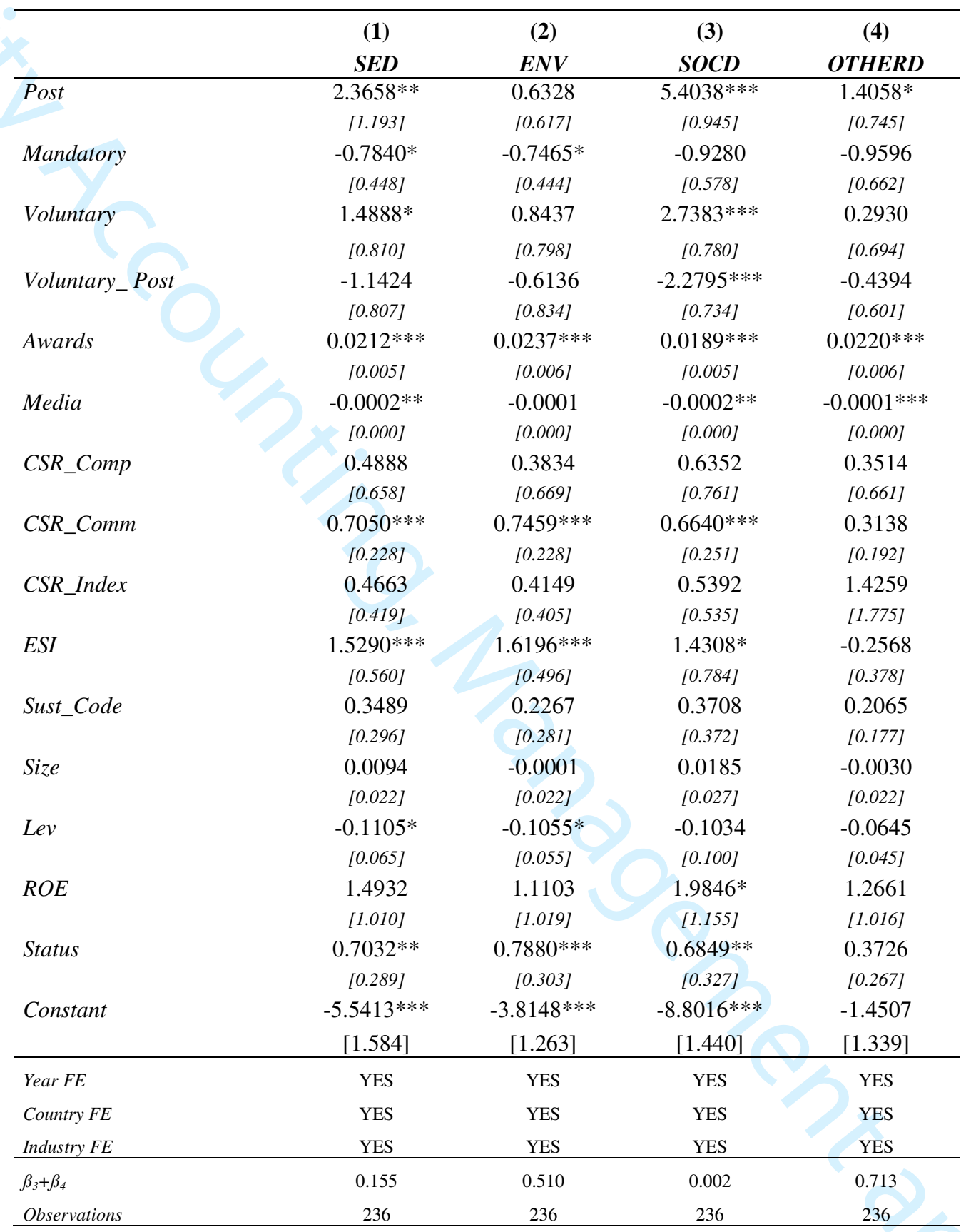

See Appendix 4 for variable definitions.

Robust standard errors are reported in brackets.

$* * * \mathrm{p}<0.01, * * \mathrm{p}<0.05, * \mathrm{p}<0.1$ 


\section{APPENDIX}

\section{Appendix A1. Summary of literature exploring the impacts of regulation on CSR reporting}

Panel A. With a focus on formal law, requiring broad disclosures

\begin{tabular}{|c|c|c|c|}
\hline Study & Country & Type of regulation & Findings \\
\hline Bebbington and Thy, 1999 & Denmark & $\begin{array}{l}\text { Formal law, requiring broad environmental } \\
\text { disclosures }\end{array}$ & $\begin{array}{l}\text { High level of compliance but poor quality of reporting } \\
\text { noted. }\end{array}$ \\
\hline Chauvey et al., 2015 & France & Formal law, requiring broad CSR disclosures & $\begin{array}{l}\text { High levels of disclosure noted but generally low } \\
\text { informational quality suggesting regulators' objectives } \\
\text { were not met }\end{array}$ \\
\hline Costa and Agostini, 2016 & Italy & $\begin{array}{l}\text { Formal law, requiring broad environmental and } \\
\text { employee disclosures }\end{array}$ & $\begin{array}{l}\text { High levels of disclosure but low levels of completeness of } \\
\text { information, suggesting regulation was ineffective }\end{array}$ \\
\hline Frost, 2007 & Australia & $\begin{array}{l}\text { Formal law, requiring broad environmental } \\
\text { disclosures }\end{array}$ & $\begin{array}{l}\text { Increased levels of disclosure following regulation, but } \\
\text { with a considerable variation in reporting approaches. }\end{array}$ \\
\hline Ioannou and Serafeim, 2014 & $\begin{array}{l}\text { China } \\
\text { South Africa } \\
\text { Denmark } \\
\text { Malaysia }\end{array}$ & $\begin{array}{l}\text { Formal law requiring broad CSR disclosures } \\
\text { Formal law, requiring specific sustainability } \\
\text { disclosures using an 'apply or explain' approach } \\
\text { Formal law, requiring broad CSR disclosures } \\
\text { Formal law, requiring broad CSR disclosures }\end{array}$ & $\begin{array}{l}\text { Increased levels of disclosure following regulation for } \\
\text { both countries. Evidence of attempts to increase reliability } \\
\text { possibly due to the statements being assured. } \\
\text { No effect on levels of disclosure for both countries but } \\
\text { increased adaptation of voluntary guidelines such as } \\
\text { Global Compact (Denmark) and GRI (Malaysia). }\end{array}$ \\
\hline Ioannou and Serafeim, 2017 & As above & As above & $\begin{array}{l}\text { As above for China and South Africa - but by using a } \\
\text { differences-in-differences model, findings suggest an } \\
\text { increase in disclosure following introduction of regulation } \\
\text { for both Denmark and Malaysia }\end{array}$ \\
\hline $\begin{array}{l}\text { Luque-Vilchesz and } \\
\text { Larrinaga, } 2016\end{array}$ & Spain & $\begin{array}{l}\text { Formal law, requiring broad CSR disclosures } \\
\text { and publication of CSR reports }\end{array}$ & $\begin{array}{l}\text { Low compliance, decrease in publication of CSR reports, } \\
\text { and smaller than expected increase in quality, possibly due } \\
\text { to the lack of formal guidance on what to disclose. }\end{array}$ \\
\hline Weber, 2014 & China & $\begin{array}{l}\text { Formal law requiring broad CSR disclosures } \\
\text { from both central and local governments }\end{array}$ & $\begin{array}{l}\text { Increased levels of disclosure following regulation, } \\
\text { benefiting also from guidance issued by major stock } \\
\text { exchanges, with differing reporting quality }\end{array}$ \\
\hline
\end{tabular}


Panel B. With a focus on formal law, requiring specific disclosures

\begin{tabular}{|c|c|c|c|}
\hline Study & Country & Type of regulation & Findings \\
\hline Adams et al., 1995 & UK & $\begin{array}{l}\text { Formal law, requiring specific equal } \\
\text { opportunities disclosure }\end{array}$ & $\begin{array}{l}\text { Low levels of compliance as most firms only offer general } \\
\text { discussions without addressing fully the requirements }\end{array}$ \\
\hline Criado-Jimenez et al., 2008 & Spain & $\begin{array}{l}\text { Formal law, requiring specific environmental } \\
\text { disclosure }\end{array}$ & $\begin{array}{l}\text { Increased levels of disclosure of better quality but } \\
\text { considerable levels of non-compliance remain }\end{array}$ \\
\hline Day and Woodward, 2004 & UK & $\begin{array}{l}\text { Formal law, requiring specific employee } \\
\text { disclosures in directors' report }\end{array}$ & $\begin{array}{l}\text { Low levels of compliance and considerable use of } \\
\text { symbolic assurances, possibly due to the report not } \\
\text { required to be fully audited }\end{array}$ \\
\hline Fallan and Fallan, 2009 & Norway & $\begin{array}{l}\text { Formal law, requiring specific environmental } \\
\text { disclosures, which are not verified by auditors }\end{array}$ & $\begin{array}{l}\text { Low level of compliance, suggesting a voluntary approach } \\
\text { may be more suitable in improving variety of disclosure. }\end{array}$ \\
\hline Peteres and Romi, 2013 & US & $\begin{array}{l}\text { Formal law, requiring specific environmental } \\
\text { disclosures }\end{array}$ & $\begin{array}{l}\text { Low levels of compliance, suggesting management } \\
\text { withholds information }\end{array}$ \\
\hline Larrinaga et al., 2002 & Spain & $\begin{array}{l}\text { Formal law, requiring specific environmental } \\
\text { disclosure }\end{array}$ & $\begin{array}{l}\text { Very low compliance, suggesting companies do not wish } \\
\text { to disclose negative information }\end{array}$ \\
\hline Llena et al., 2007 & Spain & $\begin{array}{l}\text { Formal law, requiring specific environmental } \\
\text { disclosure }\end{array}$ & $\begin{array}{l}\text { Increased levels of disclosure with considerable variation } \\
\text { in degree of compliance and disclosure levels and quality }\end{array}$ \\
\hline Mobus, 2005 & US & $\begin{array}{l}\text { Formal law, requiring specific environmental } \\
\text { disclosures }\end{array}$ & $\begin{array}{l}\text { High levels of disclosure associated with related } \\
\text { organisational performance }\end{array}$ \\
\hline Bebbington et al., 2012 & $\begin{array}{l}\text { Spain } \\
\text { UK }\end{array}$ & $\begin{array}{l}\text { Formal law, requiring specific environmental } \\
\text { disclosures } \\
\text { Informal law, based on ACCA award criteria }\end{array}$ & $\begin{array}{l}\text { Spanish rules did not lead to significant environmental } \\
\text { liability disclosures .UK companies complied to the } \\
\text { informal requirements in their stand-alone reports }\end{array}$ \\
\hline
\end{tabular}

Panel C. Studies considering informal law

\begin{tabular}{|c|c|c|c|}
\hline Study & Country & Type of regulation & Findings \\
\hline Fallan, 2016 & Norway & $\begin{array}{l}\text { Compares formal law, with accounting standard } \\
\text { requirements and recommendations regarding } \\
\text { environmental issues }\end{array}$ & $\begin{array}{l}\text { Legal requirements are found to affect disclosure more } \\
\text { than accounting standard requirements. }\end{array}$ \\
\hline $\begin{array}{l}\text { Freedman and Stagliano, } \\
2008\end{array}$ & US & $\begin{array}{l}\text { Formal and informal law requiring specific } \\
\text { disclosure, based on mandatorily implemented } \\
\text { cap-and-trade programmes }\end{array}$ & $\begin{array}{l}\text { High levels of compliance for the mandated requirements } \\
\text { and low level of compliance for the informal requirements, } \\
\text { suggesting a lack of accountability to stakeholders }\end{array}$ \\
\hline Patten, 2000 & US & $\begin{array}{l}\text { Informal law, based on stock exchange guidance } \\
\text { on specific environmental disclosures }\end{array}$ & $\begin{array}{l}\text { Increased compliance, with both specific and non-specific } \\
\text { environmental disclosure increasing }\end{array}$ \\
\hline
\end{tabular}


Appendix A2. Summary of literature exploring CSR reporting in ASEAN

Panel A. With a focus on Annual Report

\begin{tabular}{|c|c|c|}
\hline Study & Country & Key findings \\
\hline (a) & (b) & (c) \\
\hline Teoh and Thong, 1984 & Malaysia & $\begin{array}{l}\text { Social reporting lags behind corporate social involvement. Major corporate attention is focused on } \\
\text { employees and products/services. Companies with foreign ownership more likely to provide disclosures. }\end{array}$ \\
\hline Andrew et al., 1989 & $\begin{array}{l}\text { Malaysia, } \\
\text { Singapore }\end{array}$ & $\begin{array}{l}\text { Minimal disclosure of declarative nature, driven by foreign-ownership and size/industry factors. Human } \\
\text { resource the key theme. }\end{array}$ \\
\hline Tsang, 1998 & Singapore & CSR in Singapore is still in its infancy. Need for guidelines to be formulated. \\
\hline Jamil et al., 2002 & Malaysia & $\begin{array}{l}\text { Level of reporting affected by economic depression. Companies disclose more information on human } \\
\text { resource and community involvement compared to the environment and product. }\end{array}$ \\
\hline $\begin{array}{l}\text { Connely and } \\
\text { Limpaphayom, } 2004\end{array}$ & Thailand & $\begin{array}{l}\text { No significant relationship between environmental reporting and accounting performance but positive } \\
\text { relationship of reporting with market valuation. }\end{array}$ \\
\hline $\begin{array}{l}\text { Kuasirikun and Sherer, } \\
2004\end{array}$ & Thailand & $\begin{array}{l}\text { Minimal disclosure (primarily employee and environmentally related) of generally poor quality, which } \\
\text { misrepresents underlying CSR issues. }\end{array}$ \\
\hline $\begin{array}{l}\text { Thompson and Zakaria, } \\
2004\end{array}$ & Malaysia & $\begin{array}{l}\text { Minimal disclosure explained by the lack of government and public pressure particularly regarding } \\
\text { environmental disclosure as well as lack of perceived benefits. }\end{array}$ \\
\hline $\begin{array}{l}\text { Ratanajongkol et al., } \\
2006\end{array}$ & Thailand & $\begin{array}{l}\text { Increased use of disclosure over time with emphasis on human resources, and on providing information of } \\
\text { positive nature, suggesting CSR reporting reflects social exposure. }\end{array}$ \\
\hline Gunawan, 2007 & Indonesia & Minimal disclosure (primarily product related). Key motivation is compliance to stakeholder needs. \\
\hline Mirfazli, 2008 & Indonesia & Identified 'high profile' companies publish more disclosure than 'low profile' ones. \\
\hline Saleh, 2009 & Malaysia & Findings suggest a greater disclosure emphasis on employee and community compared to the environment. \\
\hline Gunawan, 2010 & Indonesia & $\begin{array}{l}\text { Corporate governance and employee disclosure shows the highest, and environment the lowest, extent. } \\
\text { Product disclosure is the highest, and community disclosure the lowest, expectation by stakeholders. }\end{array}$ \\
\hline Sawani et al., 2010 & Malaysia & $\begin{array}{l}\text { CSR reporting info integrated in the annual report and is not assured due to low level of awareness and the } \\
\text { absence of legislative pressure. }\end{array}$ \\
\hline Amran and Haniffa, 2011 & Malaysia & Coercive, normative and mimetic mechanisms of isomorphism all contribute to Malaysian CSR disclosure. \\
\hline Le, 2011 & Vietnam & Minimal disclosure, particularly in the area of human rights, although a growing trend is observed. \\
\hline Kuasirikun, 2011 & Thailand & Unlike men, women are generally portrayed in subsidiary roles in annual reports. \\
\hline Cahaya et al., 2012 & Indonesia & $\begin{array}{l}\text { Low levels of labour disclosure with more emphasis on skills and lifelong learning and less on health and } \\
\text { safety and equality in pay. Government and foreign ownership significantly affect related disclosure. }\end{array}$ \\
\hline
\end{tabular}




\begin{tabular}{|c|c|c|}
\hline (a) & (b) & (c) \\
\hline Haji, 2013 & Malaysia & $\begin{array}{l}\text { Significant increase in both the extent and the quality of reporting from } 2006 \text { to 2009. Disclosure affected } \\
\text { by director ownership, government ownership and company size. }\end{array}$ \\
\hline Anas et al., 2015 & Malaysia & $\begin{array}{l}\text { Companies publish more disclosure related to community and environment than workplace and } \\
\text { marketplace. Awards significantly affect both the extent and the quality of disclosure. }\end{array}$ \\
\hline
\end{tabular}

Panel B. With a focus on CSR reports and other disclosure media

\begin{tabular}{|c|c|c|}
\hline Study & Country & Key findings \\
\hline $\begin{array}{l}\text { Williams and Pie, } \\
1999\end{array}$ & Singapore, Malaysia & $\begin{array}{l}\text { Singaporean companies significantly publish more CSR disclosure on the website compared to annual } \\
\text { report whereas Malaysian companies show no difference. Web info is also of a comparatively more } \\
\text { narrative nature and has a greater emphasis on product and customer themes. }\end{array}$ \\
\hline Welford, 2004 & $\begin{array}{l}\text { Singapore, Malaysia, } \\
\text { Thailand }\end{array}$ & $\begin{array}{l}\text { Limited written policies by Asian companies overall and particularly on child labour issues, compared to } \\
\text { European companies. }\end{array}$ \\
\hline $\begin{array}{l}\text { Chapple and } \\
\text { Moon, } 2005\end{array}$ & $\begin{array}{l}\text { Indonesia, Malaysia, } \\
\text { Philippines, Singapore, } \\
\text { Thailand }\end{array}$ & $\begin{array}{l}\text { CSR reporting in websites varies considerably among countries, which is not explained by development. } \\
\text { Companies with foreign ownership more likely to provide disclosures. For Thailand and Singapore main } \\
\text { community issue is education and training. For Malaysia and Philippines, focus is on environment and } \\
\text { conservation. Indonesian companies show lower levels of involvement with emphasis on agriculture and } \\
\text { local economic development. }\end{array}$ \\
\hline ACCA, 2010 & $\begin{array}{l}\text { Indonesia, Malaysia, } \\
\text { Philippines, Singapore, } \\
\text { Thailand }\end{array}$ & $\begin{array}{l}\text { Notes a rise in the number of companies publishing stand-alone reports. Identifies industry and country } \\
\text { effects. Disclosure may have been influenced by the introduction of regulation in Indonesia and Malaysia } \\
\text { as well as by voluntary initiatives and awards. Interview evidence highlighted the need for assurance. }\end{array}$ \\
\hline $\begin{array}{l}\text { Forbes and } \\
\text { McIntosh, } 2011\end{array}$ & $\begin{array}{l}\text { Indonesia, Malaysia, } \\
\text { Philippines, Singapore, } \\
\text { Thailand, Vietnam }\end{array}$ & $\begin{array}{l}\text { Indicates a greater adoption of GRI guidelines by companies in Philippines, Singapore and Malaysia, } \\
\text { compared to Thailand, Indonesia and Vietnam. }\end{array}$ \\
\hline $\begin{array}{l}\text { Djajadikerta and } \\
\text { Trireksani, } 2012\end{array}$ & Indonesia & $\begin{array}{l}\text { Generally low extent of disclosure in listed companies' websites, with no difference shown between } \\
\text { sensitive and non-sensitive industries. Findings suggest use of disclosure to gain societal support. }\end{array}$ \\
\hline $\begin{array}{l}\text { Ioannou and } \\
\text { Serafeim, } 2014\end{array}$ & Malaysia & $\begin{array}{l}\text { No effect of regulation on levels of disclosure across different disclosure media but increased adaptation of } \\
\text { voluntary guidelines such as GRI. Also notes lack of assurance. }\end{array}$ \\
\hline KPMG, 2016 & $\begin{array}{l}\text { Indonesia, Malaysia, } \\
\text { Philippines, Singapore, } \\
\text { Thailand, Vietnam }\end{array}$ & $\begin{array}{l}\text { Notes a considerable growth in both mandatory and voluntary initiatives in the ASEAN region. Mandatory } \\
\text { initiatives are usually imposed by stock exchanges. Suggests that in both Malaysia and Indonesia } \\
\text { regulation has considerably influenced the growth in CSR reporting. }\end{array}$ \\
\hline $\begin{array}{l}\text { Ioannou and } \\
\text { Serafeim, } 2017\end{array}$ & Malaysia & $\begin{array}{l}\text { By using a differences-in-differences model, findings suggest an increase in disclosure across reporting } \\
\text { media following introduction of regulation. }\end{array}$ \\
\hline
\end{tabular}




\section{Appendix A3. Sample distribution}

Panel A. Sample distribution across time

\begin{tabular}{cccccc}
\hline Year & $\begin{array}{c}\text { Indonesia } \\
\text { and } \\
\text { Malaysia }\end{array}$ & $\begin{array}{c}\text { Other } \\
\text { countries }\end{array}$ & Freq. & Percent & Cum. \\
\hline 2002 & 1 & 2 & 3 & 1.27 & 1.27 \\
2003 & 2 & 1 & 3 & 1.27 & 2.54 \\
2004 & 1 & 1 & 2 & 0.85 & 3.39 \\
2005 & 3 & 1 & 4 & 1.69 & 5.08 \\
2006 & 7 & 3 & 10 & 4.24 & 9.32 \\
2007 & 11 & 10 & 21 & 8.90 & 18.22 \\
2008 & 17 & 15 & 32 & 13.56 & 31.78 \\
2009 & 15 & 21 & 36 & 15.25 & 47.03 \\
2010 & 20 & 29 & 49 & 20.76 & 67.80 \\
2011 & 24 & 42 & 66 & 27.97 & 95.76 \\
2012 & 5 & 5 & 10 & 4.24 & 100.00 \\
Total & 106 & 130 & 236 & 100.00 & \\
\hline
\end{tabular}

\section{Panel B. Sample distribution across countries}

\begin{tabular}{cccccc}
\hline Country & 2002-2006 & 2007-2012 & Freq. & Percent & Cum. \\
\hline Brunei & 0 & 2 & 2 & 0.85 & 0.85 \\
Cambodia & 4 & 1 & 5 & 2.12 & 2.97 \\
Indonesia & 8 & 54 & 62 & 26.27 & 29.24 \\
Laos & 0 & 1 & 1 & 0.42 & 29.66 \\
Malaysia & 6 & 38 & 44 & 18.64 & 48.31 \\
Philippines & 0 & 41 & 41 & 17.37 & 65.68 \\
Singapore & 1 & 41 & 42 & 17.80 & 83.47 \\
Thailand & 3 & 32 & 35 & 14.83 & 98.31 \\
Vietnam & 0 & 4 & 4 & 1.69 & 100.00 \\
Total & 22 & 214 & 236 & 100.00 & \\
\hline
\end{tabular}




\section{Appendix A4. Variable definition}

\begin{tabular}{|c|c|c|}
\hline Name & Label & Definition \\
\hline Str & $\begin{array}{l}\text { Strategy and Analysis } \\
\text { Disclosure Score }\end{array}$ & Self-constructed index for Strategy and Analysis Disclosure \\
\hline$O P$ & $\begin{array}{l}\text { Organisation Profile } \\
\text { Disclosure Score }\end{array}$ & Self-constructed index for Organisation Profile Disclosure \\
\hline$R P$ & $\begin{array}{l}\text { Report Parameters Disclosure } \\
\text { Score }\end{array}$ & Self-constructed index for Report Parameters Disclosure \\
\hline$E c o \_D$ & $\begin{array}{l}\text { Economic Performance } \\
\text { Disclosure Score }\end{array}$ & Self-constructed index for Economic Performance Disclosure \\
\hline Gov_D & $\begin{array}{l}\text { Governance, Commitments } \\
\text { and Engagement Disclosure } \\
\text { Score }\end{array}$ & $\begin{array}{l}\text { Self-constructed index for Governance, Commitments and } \\
\text { Engagement Disclosure }\end{array}$ \\
\hline$L a b \_D$ & $\begin{array}{l}\text { Labor Practices and Decent } \\
\text { Work Performance Disclosure } \\
\text { Score }\end{array}$ & $\begin{array}{l}\text { Self-constructed index for Labor Practices and Decent Work } \\
\text { Performance Disclosure }\end{array}$ \\
\hline$H R \_D$ & $\begin{array}{l}\text { Human Rights Performance } \\
\text { Disclosure Score }\end{array}$ & $\begin{array}{l}\text { Self-constructed index for Human Rights Performance } \\
\text { Disclosure }\end{array}$ \\
\hline Prod_D & $\begin{array}{l}\text { Product Responsibility } \\
\text { Performance Disclosure Score }\end{array}$ & $\begin{array}{l}\text { Self-constructed index for Product Responsibility } \\
\text { Performance Disclosure }\end{array}$ \\
\hline So_D & $\begin{array}{l}\text { Society Performance } \\
\text { Disclosure Score }\end{array}$ & Self-constructed index for Society Performance \\
\hline END & $\begin{array}{l}\text { Environmental Disclosure } \\
\text { Score }\end{array}$ & Self-constructed index for Environmental Disclosure \\
\hline$S O C D$ & Social Disclosure Score & $\begin{array}{l}\text { Self-constructed index for Overall Social Disclosure (Labor } \\
\text { Practices and Decent Work, Human Rights, Product } \\
\text { Responsibility, Society Performance). }\end{array}$ \\
\hline$S E D$ & $\begin{array}{l}\text { Social \& Environmental } \\
\text { Disclosure Score }\end{array}$ & $\begin{array}{l}\text { Self-constructed index for Overall Social and Environmental } \\
\text { Disclosure }\end{array}$ \\
\hline OTHERD & Other Disclosure Score & $\begin{array}{l}\text { Self-constructed index for other type of disclosure required } \\
\text { by the GRI (Strategy, Operations and Report profile, } \\
\text { Corporate Governance and Economic Performance) }\end{array}$ \\
\hline Post & Regulation introduction & 1 for the period ending or after 2007,0 otherwise \\
\hline Mandatory & Mandatory reporters & $\begin{array}{l}1 \text { for Indonesian and Malaysian firms that do not disclose } \\
\text { CSR until it becomes mandatory, } 0 \text { otherwise }\end{array}$ \\
\hline Voluntary & Voluntary reporters & $\begin{array}{l}1 \text { for Indonesian and Malaysian firms that disclosure CSR } \\
\text { before it became mandatory, } 0 \text { otherwise }\end{array}$ \\
\hline Awards & Awards & Total number of CSR awards received \\
\hline Media & Media exposure & Total number of press articles \\
\hline CSR_Comp & CSR compensation & $\begin{array}{l}1 \text { for firms linking CSR to executive compensation, } 0 \\
\text { otherwise }\end{array}$ \\
\hline CSR_Comm & CSR committee & 1 for firms with a dedicated CSR committee, 0 otherwise \\
\hline CSR_Index & CSR reputation & 1 for firms belonging on a CSR index, 0 otherwise \\
\hline ESI & $\begin{array}{l}\text { Environmental Sensitive } \\
\text { Industry }\end{array}$ & $\begin{array}{l}1 \text { if the company belongs to environmentally sensitive } \\
\text { industries, } 0 \text { otherwise }\end{array}$ \\
\hline Sust_Code & Sustainability code & 1 if the company follows a sustainability code, 0 otherwise \\
\hline Size & Firm size & Log (total assets) \\
\hline Lev & Leverage & Financial debts divided by total assets \\
\hline$R O E$ & Profitability & Net income divided by book value of equity \\
\hline Status & Firm listing status & 1 if the company is private, 0 if it is publicly listed \\
\hline
\end{tabular}

